\title{
SOEP=
}

SOEPpapers

SOEPpapers
on Multidisciplinary Panel Data Research

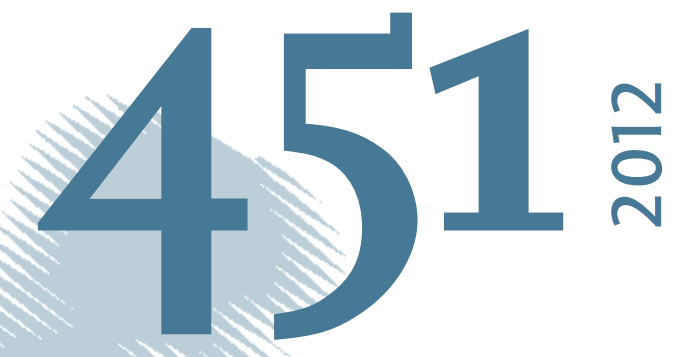

\section{Completing the Bathtub? The Development of Top Incomes in Germany, 1907-2007}




\section{SOEPpapers on Multidisciplinary Panel Data Research}

at DIW Berlin

This series presents research findings based either directly on data from the German SocioEconomic Panel Study (SOEP) or using SOEP data as part of an internationally comparable data set (e.g. CNEF, ECHP, LIS, LWS, CHER/PACO). SOEP is a truly multidisciplinary household panel study covering a wide range of social and behavioral sciences: economics, sociology, psychology, survey methodology, econometrics and applied statistics, educational science, political science, public health, behavioral genetics, demography, geography, and sport science.

The decision to publish a submission in SOEPpapers is made by a board of editors chosen by the DIW Berlin to represent the wide range of disciplines covered by SOEP. There is no external referee process and papers are either accepted or rejected without revision. Papers appear in this series as works in progress and may also appear elsewhere. They often represent preliminary studies and are circulated to encourage discussion. Citation of such a paper should account for its provisional character. A revised version may be requested from the author directly.

Any opinions expressed in this series are those of the author(s) and not those of DIW Berlin. Research disseminated by DIW Berlin may include views on public policy issues, but the institute itself takes no institutional policy positions.

The SOEPpapers are available at

http://www.diw.de/soeppapers

\section{Editors:}

Jürgen Schupp (Sociology, Vice Dean DIW Graduate Center)

Gert G. Wagner (Social Sciences)

Conchita D'Ambrosio (Public Economics)

Denis Gerstorf (Psychology, DIW Research Professor)

Elke Holst (Gender Studies)

Frauke Kreuter (Survey Methodology, DIW Research Professor)

Martin Kroh (Political Science and Survey Methodology)

Frieder R. Lang (Psychology, DIW Research Professor)

Henning Lohmann (Sociology, DIW Research Professor)

Jörg-Peter Schräpler (Survey Methodology, DIW Research Professor)

Thomas Siedler (Empirical Economics)

C. Katharina Spieß (Empirical Economics and Educational Science)

ISSN: 1864-6689 (online)

German Socio-Economic Panel Study (SOEP)

DIW Berlin

Mohrenstrasse 58

10117 Berlin, Germany

Contact: Uta Rahmann | soeppapers@diw.de 


\title{
Completing the Bathtub? \\ The Development of Top Incomes in Germany, 1907-2007
}

\author{
Christina Anselmann* / Hagen M. Krämer*
}

June 6, 2012

\begin{abstract}
This paper examines the evolution of top incomes in Germany from 1907-2007 with a special focus on past decades. A more detailed analysis of German top incomes is conducted, beginning with a review of selected income distribution measures which indicate that high incomes have played a significant role for income divergence in recent years. Based on new data it is shown that top income shares have indeed increased substantially in the recent past, a process which is mainly due to a relative rise in employment rather than capital income within the top income groups. Finally, some theories explaining high incomes of the "working rich" are discussed.
\end{abstract}

Keywords: top income shares, income dispersion, executive compensation JEL Classification: D31, J30

\footnotetext{
* Karlsruhe University of Applied Sciences, Department of Management and Engineering, Moltkestr. 30, D-76133 Karlsruhe (Germany). Contact email: hagen.kraemer@hs-karlsruhe.de
} 


\section{Introduction}

For several months, supporters of the Occupy Movement have been publicly criticizing the rising income and wealth disparity in the United States and various other countries around the world. Their main slogan, "We are the 99 percent!”, highlights the issue of the growing gap between rich and poor, explicitly the income and wealth concentration among the top one percent of the population compared to the bottom 99 percent. Shortly after the initiation of the protest movement, the US Congressional Budget Office published a report in fall 2011 stating that real after-tax income grew by 275 percent for the top one percent of all US households in the period from 1979 to 2007 whereas after-tax income for all other income fractiles only increased by a maximum of 65 percent. Eventually, solely the upper quintile - and within mainly the top one percent - could increase its share of after-tax income while all other income groups saw a decline in their income shares (cf. Congressional Budget Office 2011).

During the past years, several studies revealed that the evolution of high incomes has had a significant impact on overall income inequality. For instance, Alvaredo (2010, pp.5) mentions that in the United States the Gini coefficient for the bottom 99 percent of the population only increased by 3.2 percentage points, whereas the Gini coefficient including the top one percent rose by 8.8 percentage points between 1976 and 2006. Looking at the long-term development in the US from 1917 to 2007, Figure 1 gives a broader picture of overall trends. Until the late 1920s the income share of the top ten percent of the distribution climbed to a rather high level of some 46 percent, and subsequently declined moderately during the Great Depression. It then, however, decreased substantially during World War II and afterwards remained relatively constant for a long period between 1945 and 1980. Starting in the early 1980s the share of the top ten percent experienced a remarkable recovery and in 2007 restored to its level of the late 1920s. 
Figure 1: The top decile income share in the United States, 1917-2007

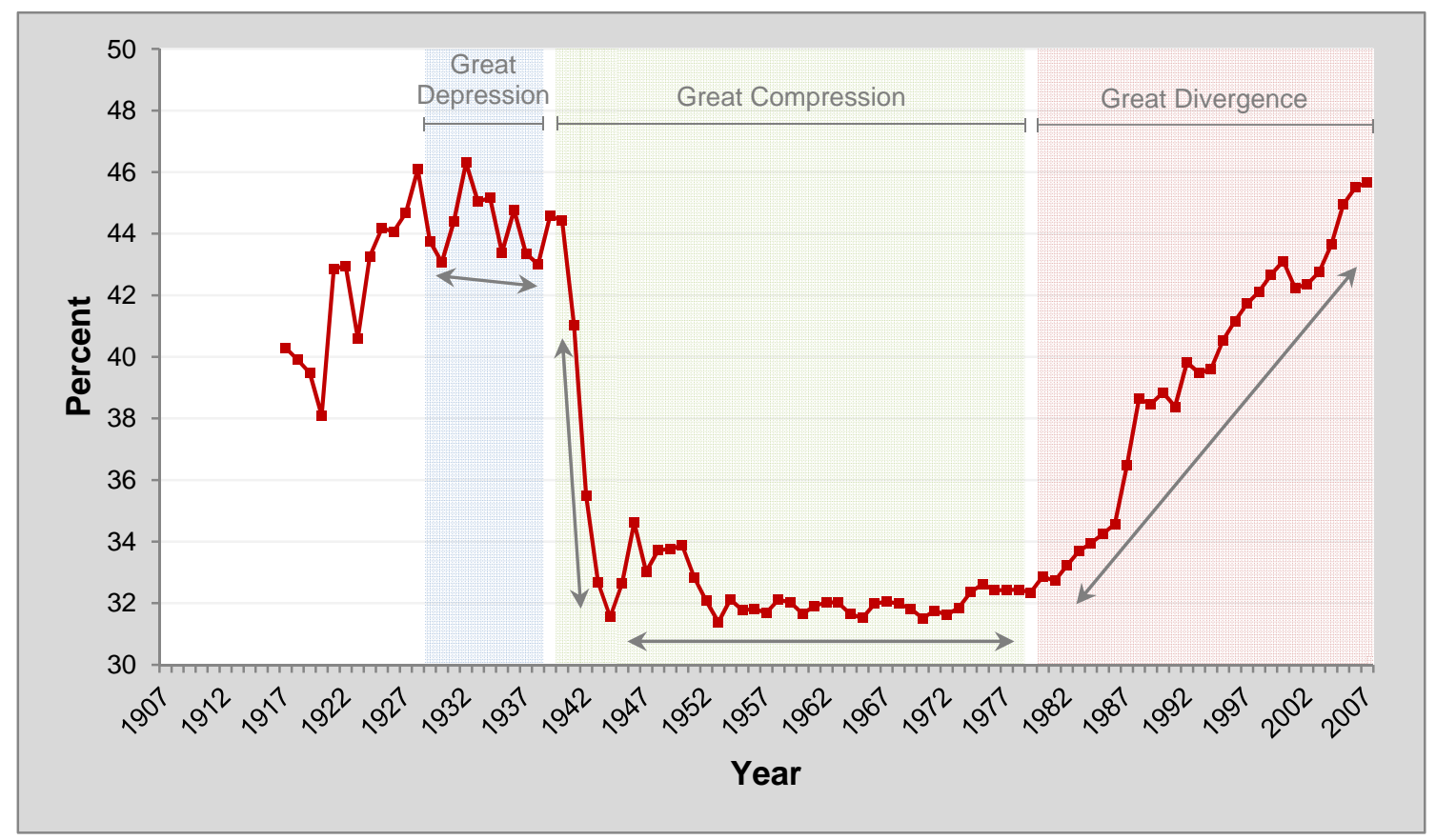

Figure 2: The top decile income share in Germany, 1907-1998

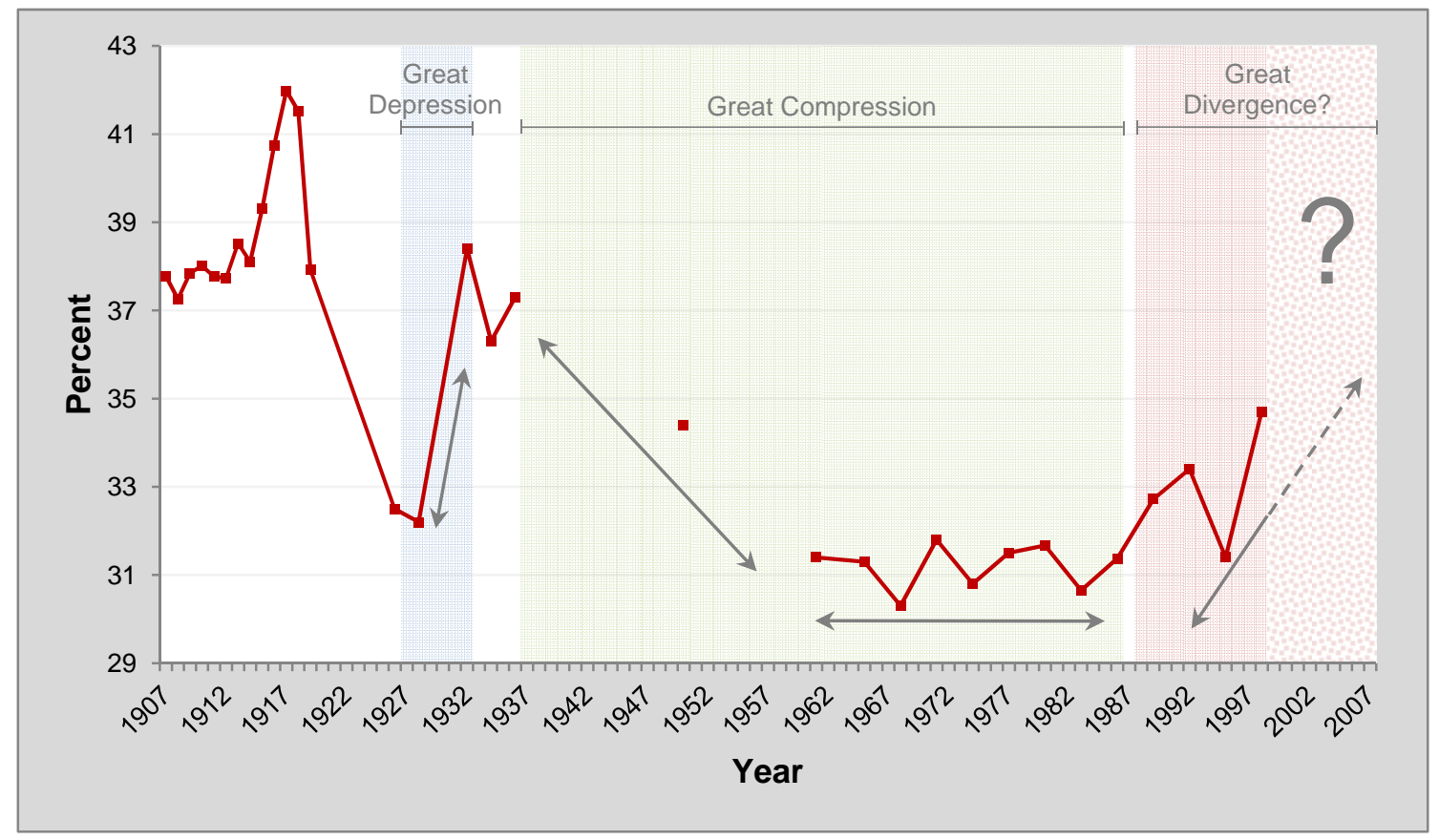

Source (Figures 1 and 2): Alvaredo et al. 2012, Tables United States and Germany. The developments which mainly dominated the general pattern of top income shares over the twentieth century are highlighted in color: The years of the Great Depression are shaded in blue, the years of the Great Compression are shaded in green, and the years of the Great Divergence are shaded in red.

By calling the period between the early 1940s and the end of the 1970s the Great Compression, the present paper follows Goldin and Margo (1991) who coined 
this phrase to describe the sharp downturn of top income shares during World War II and its constancy in subsequent decades. In light of the significant rise in income differences, the period since 1980 can, in contrast, be called the Great Divergence (Krugman 2007). To sum up, when looking at Figure 1 one can imagine the development of the top decile share in US gross income to exhibit a U- or "bathtub"-shape over the eighty years between 1927 and 2007.

According to Atkinson and Piketty, the strong growth in top income shares has been occurring in several English-speaking countries during the last decades, whereas in Continental Europe “[...] there has not been a U-shaped pattern over the twentieth century.” (Atkinson/Piketty 2007b, p. 541) The present paper is mainly concerned with the developments in Germany and challenges the view that the recovery of top incomes cannot be found there. Figure 2 illustrates that the top decile income share in Germany decreased substantially in the years of hyperinflation ${ }^{2}$ after the First World War but, other than in the United States, increased during the Great Depression. ${ }^{3}$ Another rise in top income shares after the Nazis came to power was then followed by a sharp downturn subsequent to the Second World War. ${ }^{4}$ Similar to the US-development, we find a Great Compression period in Germany, yet it ended later: From 1961 until the beginning of the 1990s the share of the top ten percent oscillated on a rather low and constant

2 Further information on the development of top income shares during the years of hyperinflation is provided by Dell 2007, pp. 372.

3 As can be seen from a comparison between Figures 1 and 2, the blue shaded areas indicating the Great Depression are not covering the same years in the United States and in Germany. Following Dell (2007), in Germany the years from 1933 (seizure of power by the Nazis) until the outbreak of the Second World War are considered separately (cf. Dell 2007, pp. 373), whereas such a differentiation is not necessary for the United States.

During the Great Depression, the evolution of the German top decile income share was exceptionally dominated by the developments of lower income fractiles within the top ten percent of the distribution. While the income ratios of the highest income groups (top one percent, top 0.01 percent) decreased only slightly between 1929 and 1933, the lower income fractiles (top 10-5 percent, top 5-1 percent) experienced a sharp rise in their income shares. "On the one hand, the higher part of the top decile did not significantly suffer of the Depression and of the deflationary measures imposed by the [...] government at the time, and on the other hand, the lower part of the top decile, being mainly composed of (short-term downward rigid) wages [...], deflation did not hit them and even made their relative weight grow.“ (Dell 2007, pp. 373). However, after the seizure of power by the Nazis in 1933, this development reversed and the top groups regained income share, whereas the ratios of lower income groups within the top ten percent declined.

4 It should be noted, however, that the series from 1937 until 1960 is incomplete (see Figure 2). 
level between 30 and 33 percent. The stability of this share, which unlike in the US can still be found in the 1980s and early 1990s, seems to support the "stylized fact" of rigid unchanging wage structures in the German labor market (cf. Atkinson 2008, p. 3). Although there appears to be a slight upward trend since the late 1980s, it is obvious that the evolution of top income shares in Germany did not finish a complete bathtub-shaped pattern in the twentieth century. In contrast to the data for the United States which clearly indicate a Great Divergence, the series for Germany is not applicable to confirm a similar evolution. However, Atkinson and Piketty are analyzing data which end in 1998, so the question arises whether the modest increase that emerged in the late 1980s has continued during the past years. Has the "bathtub" been completed in Germany in the recent past, or is it still valid to refer to a non-U-shaped pattern of German high income shares?

The second question addressed in the present paper concerns the composition of high incomes. Intuitively, one would assume that incomes at the top of the distribution are mainly composed of capital income, while wages and salaries play only a minor role. Thus, it is quite surprising that prior to World War II incomes of the top groups in the US were predominantly composed of capital income, whereas the recent rise in high income shares is primarily due to an increase in employment income (cf. OECD 2011a, pp. 347). Can similar patterns be found in German top incomes as well?

To shed more light on this, the present paper examines the evolution of top incomes over the past decades in more detail. The next section starts with a review of some appropriate income measures which demonstrate that in Germany top incomes have also increased significantly during the past years. Based on new data from The World Top Incomes Database by Alvaredo/Atkinson/Piketty/Saez (2012) as well as recent figures by Bach/Corneo/Steiner (2009, 2011), a more detailed analysis of German high incomes is then conducted in part 3. Furthermore, this section highlights the 
growing impact of labor income within top incomes and stresses the importance of the “working rich”. Part 4 discusses some underlying theories about top incomes. Section 5 finally summarizes the main results and draws some conclusions.

\section{Some general trends in personal income distribution in Germany}

According to recent OECD studies, Germany is one of the countries in which overall income dispersion increased most significantly over the past decades. Between 1985 and 2008, the Gini coefficient rose from 0.251 to 0.295 and thus grew by more than four percentage points. ${ }^{5}$ Although the German Gini index is still slightly below the OECDaverage (0.316), higher growth rates were recorded only in Sweden, New Zealand, Finland, and Israel (cf. OECD 2011a, pp. 22; OECD 2012a, pp. 80). Time-wise, it is striking that income differences first started to increase in some English-speaking nations at the beginning of the 1980s, whereas this development set in only about a decade later in other countries. In Germany, the growth of the Gini index was almost twice as large between the mid-1990s and 2008 as in the first sub-period from 1985 to the mid-1990s (cf. OECD 2012a, pp. 80). This development seems to be in line with the evolution of top income shares illustrated in Figures 1 and 2: While the income share of the top decile in the US started to rise again at the beginning of the 1980s, the upward trend in Germany did not set in until the late 1980s and the beginning of the 1990s. However, the Gini coefficient is especially sensitive to changes in the middle of the distribution, so its intense increase during the past years does not necessarily imply that top income shares have also grown and thereby the "bathtub" pattern of top incomes has been completed in Germany. While the OECD reports that "inequality has generally [...] [arisen] because rich households have done particularly well in comparison with middle-class

5 The Gini coefficient refers to real equivalent annual net household income (modified OECD equivalence scale). An overview of data sources and income concepts used in the present paper is listed in Appendix A.1. 
families and those at the bottom of the income distribution” (OECD 2008, p. 17), this statement still has to be confirmed for Germany by taking a closer look at some other measures which are more appropriate to indicate changes in the upper part of the distribution. Based on data from the German Socio-Ecnomic Panel Study (SOEP), a longitudinal study of private households in Germany, chosen income components and indicators are analyzed in the following. ${ }^{6}$

Figure 3: Mean and median real income in Germany, 1984-2010

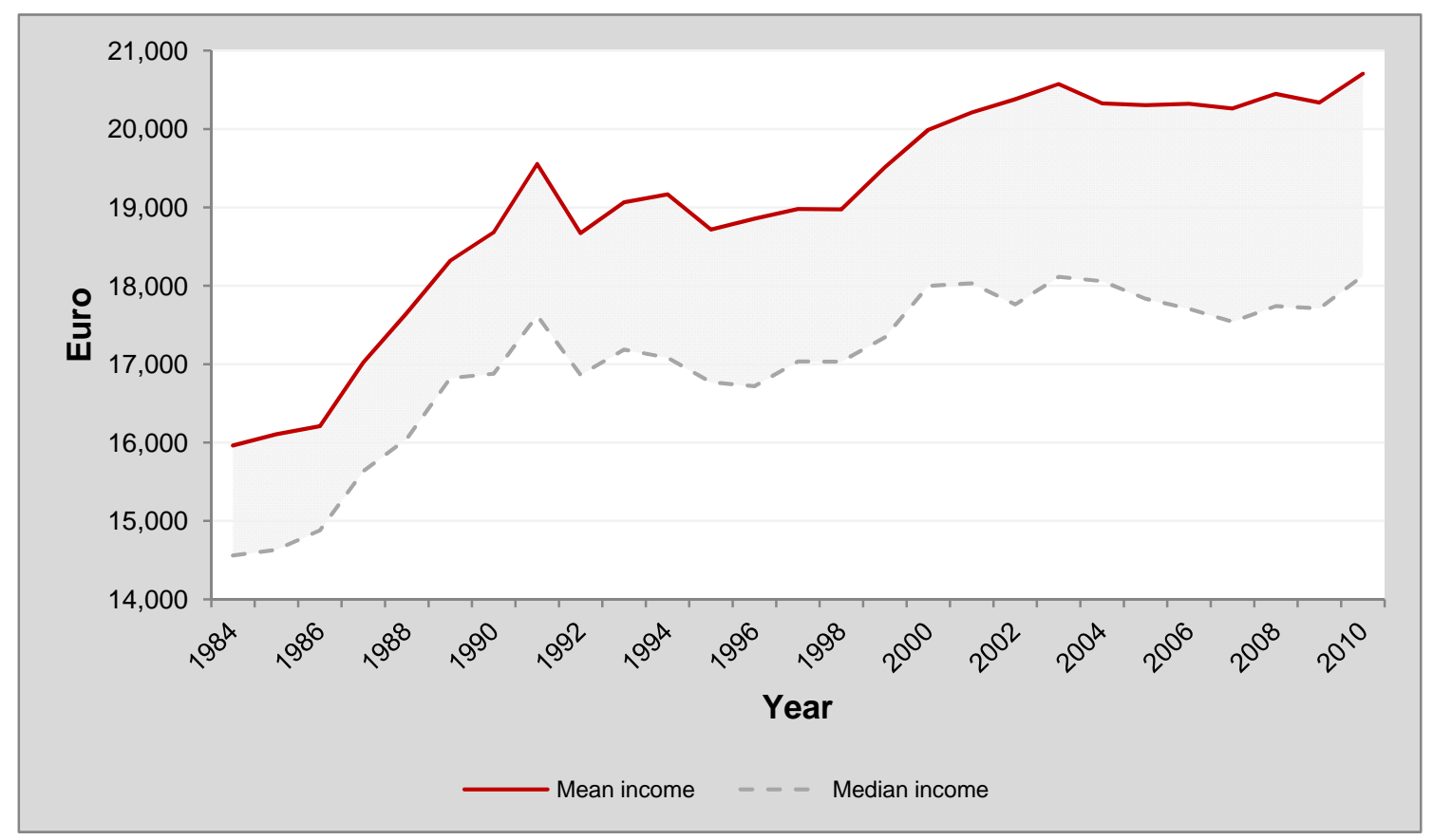

Source: German Socio-Economic Panel Study 2010, pp. 81. Series deflated by consumer price index (base year 2005).

A comparison between the developments of mean and median income reveals that the benefits of economic growth were spread unevenly across the German population during the past years. As illustrated by Figure 3, both income parameters increased from 1984 to 2010, but they grew to varying degrees. While average income rose by 4,745 Euro, or 29.7 percent, median income grew by only 3,567 Euro, or 24.5 percent. The gap between mean and median income started to increase at the beginning of the 1990s. However, this diverging development has even been intensifying since 2000.

\footnotetext{
6 An overview of data sources and income concepts used in the present paper is listed in Appendix A.1.
} 
While the median-to-mean income ratio accounted for 91.2 percent in 1984 and 90.0 percent in 2000, it had declined to 87.5 percent in 2010. Thus, incomes of higher income fractiles must have grown faster than those of lower income groups, leading to a rise in overall income dispersion (cf. Grabka/Frick 2008, pp. 101).

It can be seen in Figure 4 that past years incomes at the top and at the bottom of the distribution must have developed differently. The 90/10 decile ratio compares the upper income threshold of the ninth decile with the upper income threshold of the first decile. Except for the years from 1984 to 1990 and from 1995 to 1998, the indicator continuously increased during the given time period. Between 1998 and 2010, the ratio rose by 15.7 percent from 2.99 percent to 3.46 percent.

Figure 4: The development of the 90/10 decile ratio in Germany, 1984-2010

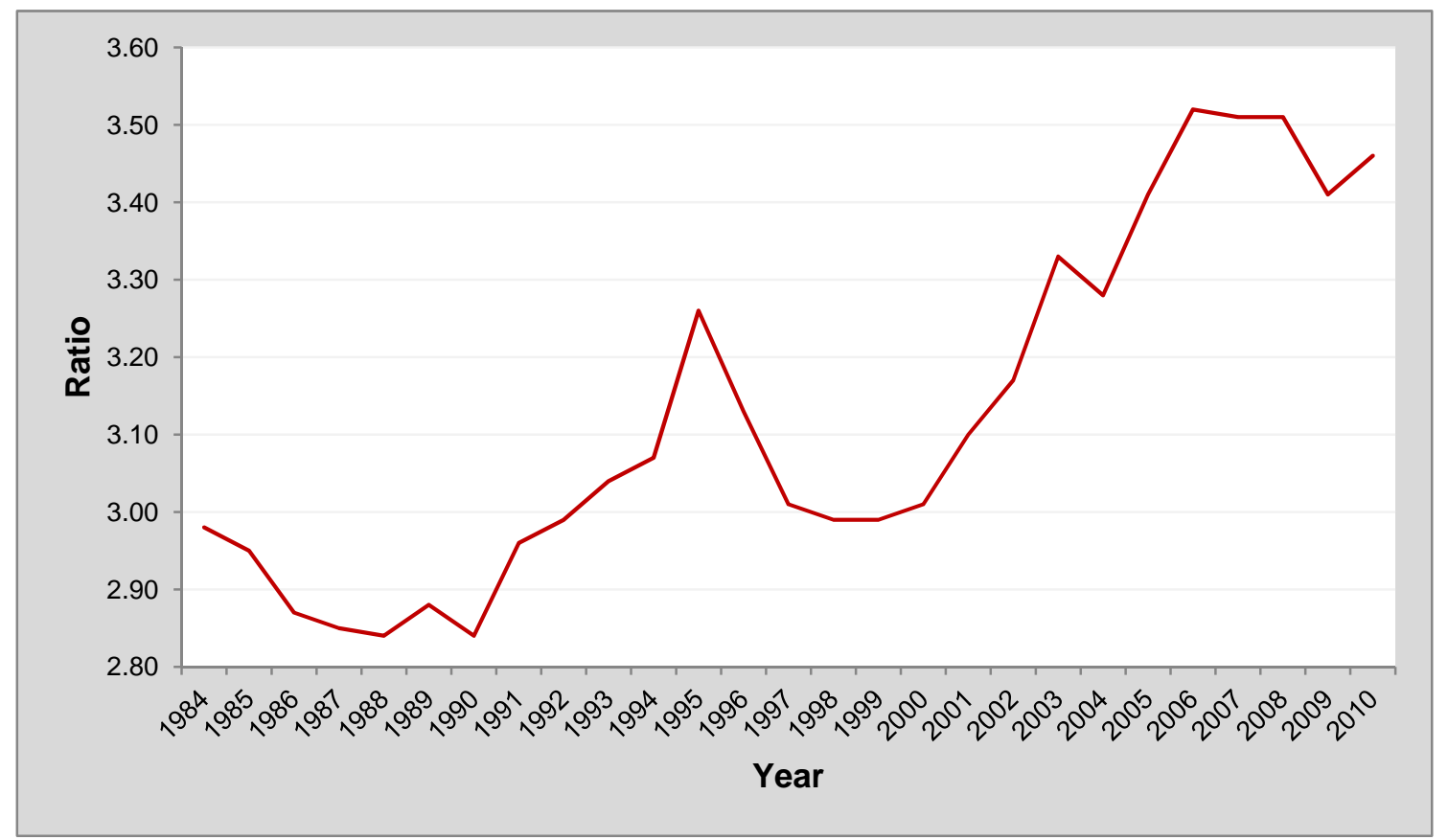

Source: German Socio-Economic Panel Study 2010, p. 83.

Since the evolution of the 90/10 decile ratio can be influenced by both developments within the first and the ninth decile, it has to be analyzed whether the distinct growth of the 90/10 decile ratio over the past years was mainly due to changes at the bottom of the income distribution, the top, or a combination of the two. For this pur- 
pose, the underlying (absolute) thresholds of both deciles are calculated. A closer look at the period from 1998 to 2010 in Figure 5 reveals that the upper income threshold of the first decile declined by 6.3 percent, whereas the threshold of the ninth decile increased by 8.2 percent. $^{7}$ The substantial growth of the $90 / 10$ decile ratio during the past years can thus be attributed to both an increase at the top of the income distribution as well as a decline at the bottom. However, the increase at the top was slightly more pronounced than the decline at the bottom.

Figure 5: First and ninth decile upper income thresholds in Germany, 1990-2010

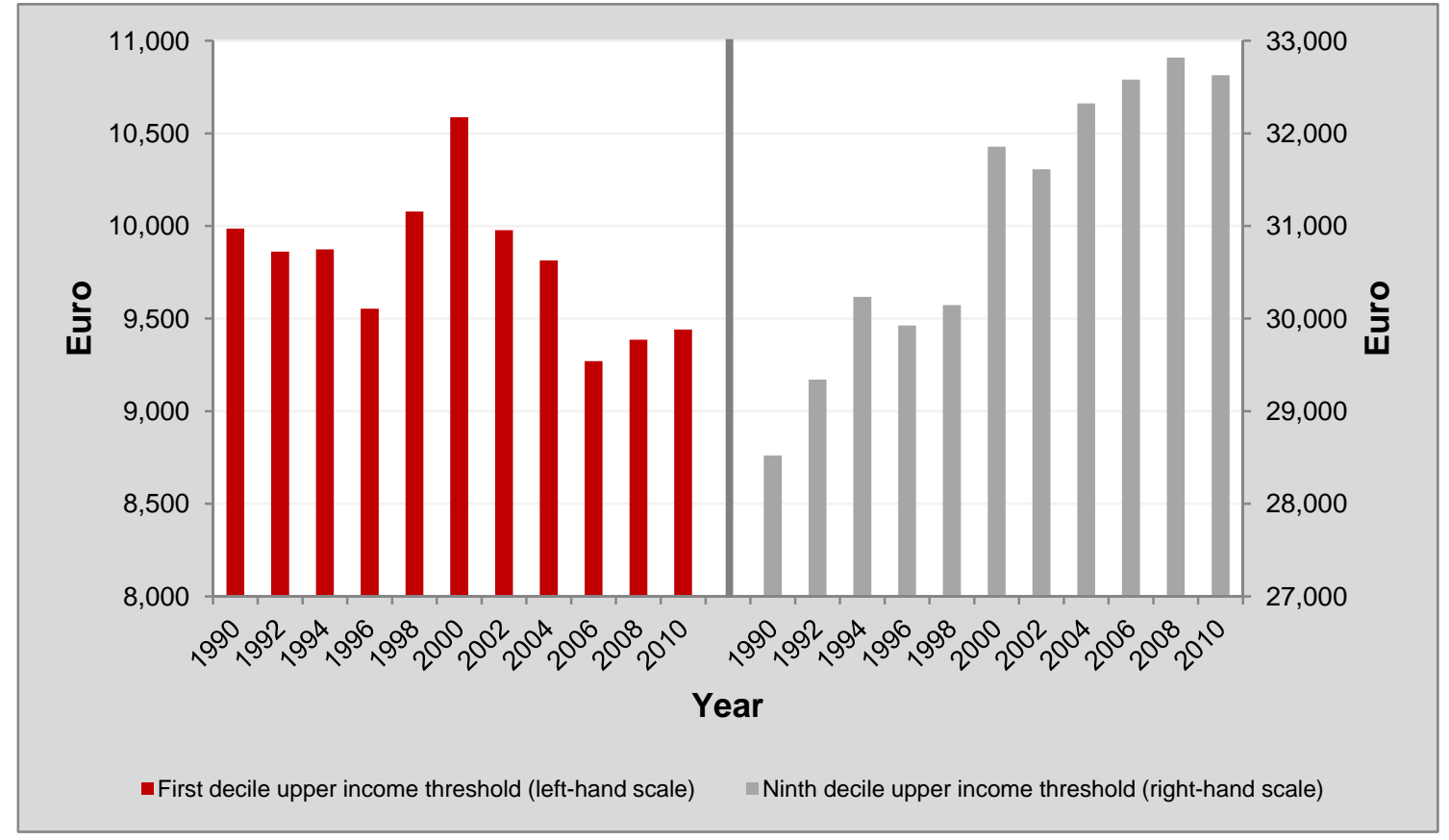

Source: German Socio-Economic Panel Study 2010, pp. 81. Series deflated by consumer price index (base year 2005).

Since the decile ratio described above is calculated on the basis of income thresholds, it is useful to also take a look at the evolution of each decile's average income. As shown below in Figure 6, the development of mean income across the ten deciles can basically be divided into two parts: While average real equivalent net household income declined in the bottom four fractiles, the upper five deciles have experienced a rise in mean income between 1999 and 2009. Average income of the fifth 
decile stagnated. Changes at either extreme end of the income distribution have also been considerably more pronounced than in the middle.

A comparison with Figure 5 furthermore reveals the following: From 1999 to 2009, the upper income threshold of the lowest decile declined by approximately 7.8 percent, whereas during the same period average income of the first decile decreased by 9.6 percent. A similar trend can be observed at the top of the income distribution: While the upper income threshold of the ninth decile (which approximately is also the lower income threshold of the tenth decile) increased by 5.0 percent between 1999 and 2009, mean income of the top decile increased by 16.6 percent. This development suggests that incomes must have changed quite unevenly across the quantiles within both the first and especially the tenth decile, a conjecture which can be confirmed by analyzing the evolution of different summary inequality measures.

Figure 6: Growth of mean real income across different income deciles in Germany, 1999-2009

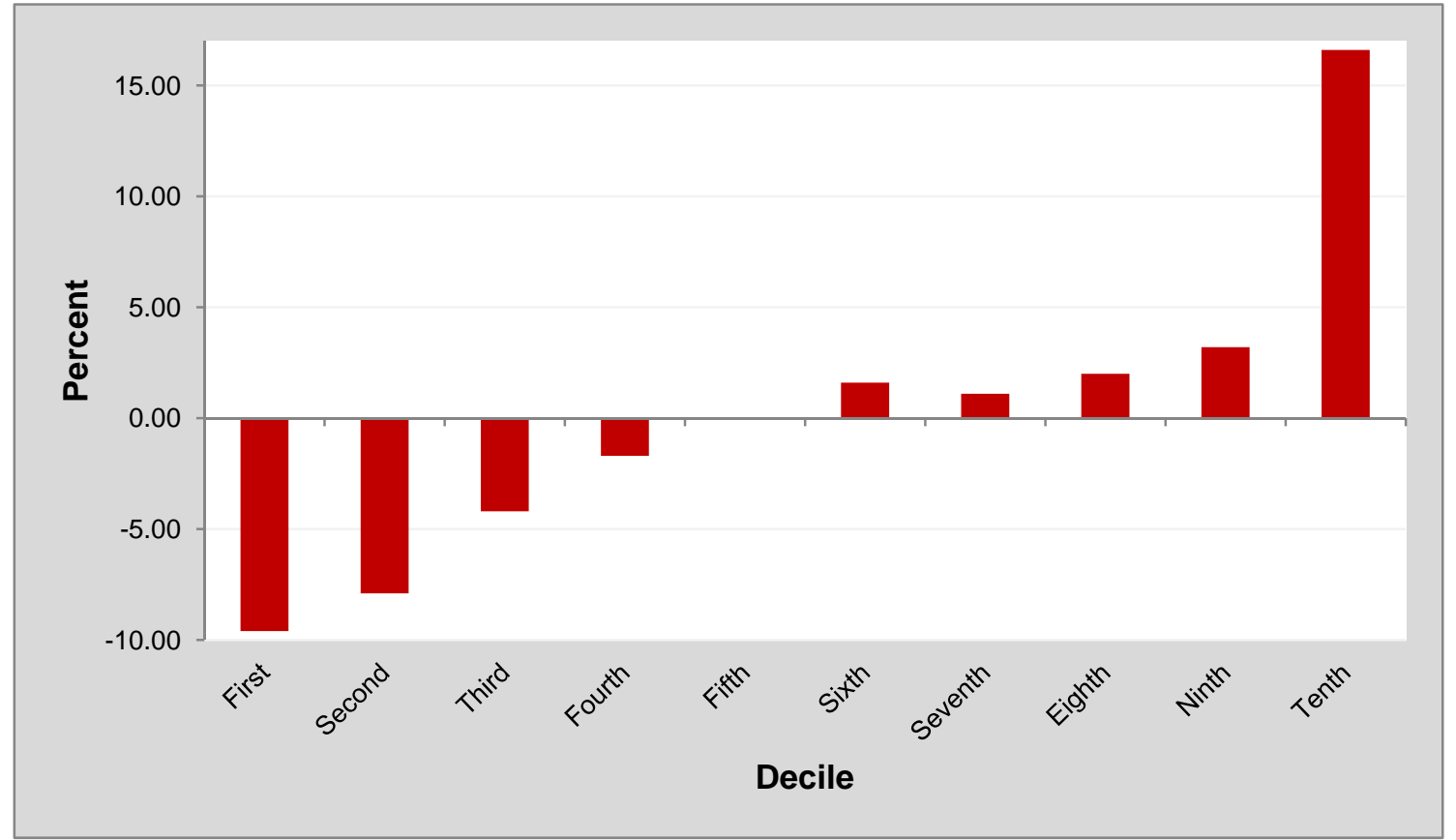

Source: Grabka 2011, p. 79.

As already mentioned above, the Gini coefficient is not the most appropriate indicator to properly outline general trends at either extreme end of the distribution 
since it is particularly sensitive to changes among middle income groups. Three indices belonging to the class of generalized entropy measures are considered instead: While the mean log deviation (MLD) is sensitive to income differences at the lower end, the Theil index is equally sensitive to transfers across the whole spectrum of distribution, and the half-squared coefficient of variation (HSCV) is sensitive to changes at the top of the distribution (cf. Hao/Naiman 2010, pp. 38; Kim/Sakamoto 2005, pp. 15). All three indicators are zero in the case of complete equality, but have no upper limit when incomes are totally distributed unequally (cf. Schwarze 1998, pp. 20). Between 1999 and 2010 the Theil index increased by 56.0 percent from 0.109 to 0.170 . During the same period, the mean log deviation rose from 0.107 to 0.145 , which represents an increase of 36.8 percent (cf. German Socio-Economic Panel Study 2010, pp. 81). Based on OECD statistics, the top-sensitive half-squared coefficient of variation increased by 93.3 percent between 2000 (0.164) and 2008 (0.317) (cf. OECD 2012b, Table Germany). According to these figures, income differences across the whole spectrum of distribution have grown substantially. However, dispersion among the rich seems to be highest and has also increased the most over the past years.

\section{The evolution of top incomes in Germany}

\subsection{Data and methods}

Although the topic of both income distribution and the evolution of top incomes have gained a renewed interest in recent years, its analysis has a long tradition: In 1915, Willford King already addressed the issue of income divergence in The Wealth and Income of the People of the United States (cf. King 1915). Less than four decades later, Kuznets calculated the income shares of some top income groups for the period from 1919 to 1948 (cf. Kuznets 1953). In subsequent years, a few more reports and books on income differences were published (e.g. The Structure of Earnings by Lydall 1968), but 
yet general interest in the subject somehow seemed to be lost. This development might partly be due to dissatisfaction with the available data, which were mainly based on household surveys covering only a short period of time and not containing the full range of information on top incomes.

At the beginning of the twenty-first century, Piketty started to use tax numbers from Internal Revenue Service to comprehensively analyze the long-run distribution of top incomes on the example of France (cf. Atkinson 2007, p. 18). Within the scope of “[...] a collective research project [...]” (Piketty 2007, p. 1), his study was followed by several other tax-based surveys on the evolution of high incomes in different countries. The results for a total of 22 nations were finally compiled in Top Incomes over the Twentieth Century by Atkinson/Piketty (2007a) and Top Incomes: A Global Perspective by Atkinson/Piketty (2010). Since 2011, the two books have been accompanied by The World Top Incomes Database by Alvaredo/Atkinson/Piketty/Saez, an online database which is probably the most comprehensive data set on top incomes currently available. The series is regularly updated and based on tax data momentarily provides long-run information on the evolution of high incomes in 26 countries (cf. Alvaredo/Atkinson/Piketty/Saez 2012). Using data from The World Top Incomes Database and recent calculations by Bach/Corneo/Steiner (2009, 2011), the evolution of German top incomes is analyzed below. ${ }^{8}$

\subsection{The evolution of top income shares in Germany}

After increasing between 1907 and 1917, the top decile income share in Germany declined substantially at the beginning of the twentieth century. Sudden rises during the First and shortly before the Second World War, “[...] the two moments [...] when Germany saw an authoritarian government take control” (Dell 2007, p. 371), were always

\footnotetext{
8 Data sources and methods are also discussed in Appendix A.
} 
followed by reductions of the top ten percent income ratio. Except for the lower income groups within the top ten percent (top 10-5 percent, top 5-1 percent), income shares did not recover in the post-World War II years, but oscillated on relatively low levels (see Appendix B). For instance, the top decile income share varied between low 30 and 33 percent in the four decades after the war (see Figure 2). ${ }^{9}$

A similar post-Second World War development can also be found in the United States (see Figure 1). According to Piketty and Saez, the high income groups in the US “[...] were simply not able, because of social, fiscal, and union pressure, to increase their salaries back to the pre-war levels in relative terms.” (Piketty/Saez 2007, p. 164) The establishment of corporate organizations and increasing unionization after 1948 (cf. Abelshauser 1983, pp. 81) provide a similar explanation for the post-war top income developments in Germany.

While high income shares in the United States had finally started to increase again at the end of the 1970s, this development had not commenced in Germany until the late 1980s/early 1990s. In 1998, the US top ten percent income share had already reached its 1938 level again and had thus almost completed a bathtub-shaped pattern, whereas this was not the case in Germany (see Figures 1 and 2). However, the income dispersion measures analyzed in section two suggest that the upward trend of German top income shares has continued over the past years.

Between 1950 and 1995, real gross income across the whole population grew by approximately 3.1 percent per year on average. Figure 7 and Table B.1 reveal that this increase was distributed quite evenly across different income groups. In general, mean income of the bottom 90 percent even grew slightly more (average annual growth rate of 3.2 percent) than average income of the top ten percent (average annual growth

9 The lower income fractiles within the top decile (top 10-5 percent, top 5-1 percent) followed a different pattern throughout the twentieth century than the highest income groups (see Appendix B). However, except for the years of the Great Depression, the general pattern of the top decile was dominated by the highest income groups. 
rate of 3.0 percent). Similar to the developments in the United States where top income shares first declined and then oscillated on a quite low and constant level after the Second World War until the beginning of the 1980s, in Germany the post-World War II period until the early 1990s can also be named the Great Compression (see Figure 2).

Figure 7: Average annual growth rates of real gross income (including capital gains)

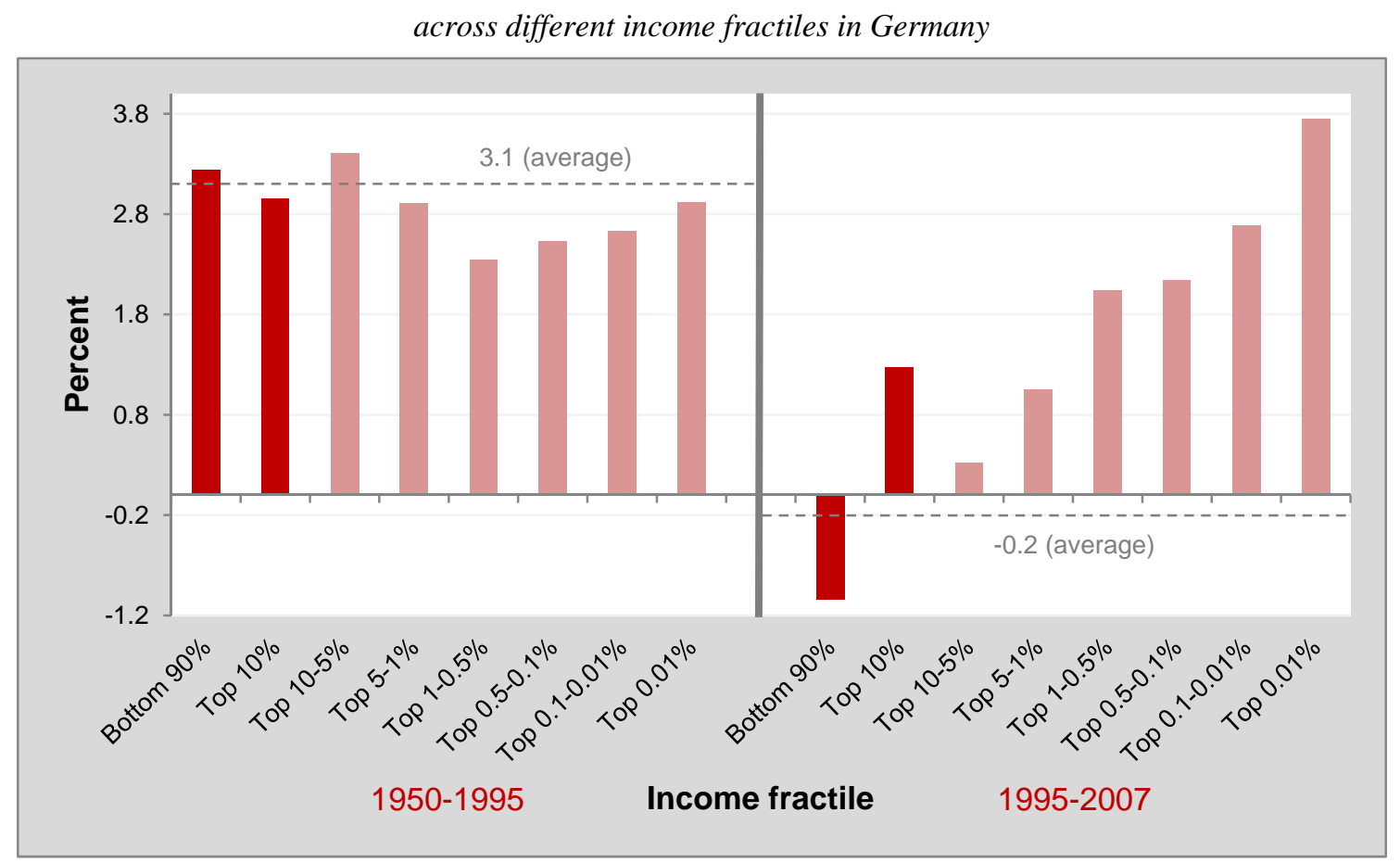

Source: Alvaredo et al. 2012, Table Germany; own calculations.

A far more unequal growth of average real gross income can be observed during the period from 1995 to 2007 . While real gross income across the whole population shrank with an average annual growth rate of -0.2 percent, it declined by -1.0 percent for the bottom 90 percent but rose for the top decile by 1.3 percent on average each year. Even the incomes of the bottom 99 percent declined with an average annual growth rate of -0.6 percent, whereas real gross income of the top one percent increased by 2.5 percent each year (see Table B.1). Compared to the years from 1950 to 1995, there has also been a change of income growth within the top decile. Between 1995 and 2007, households (i.e. families) at the very top of the tenth decile have seen their in- 
comes increase considerably more than families at the bottom of the top ten percent. How these diverging developments impacted the evolution of corresponding income shares is illustrated below.

Figure 8: The top decile income share in Germany, 1907-2007

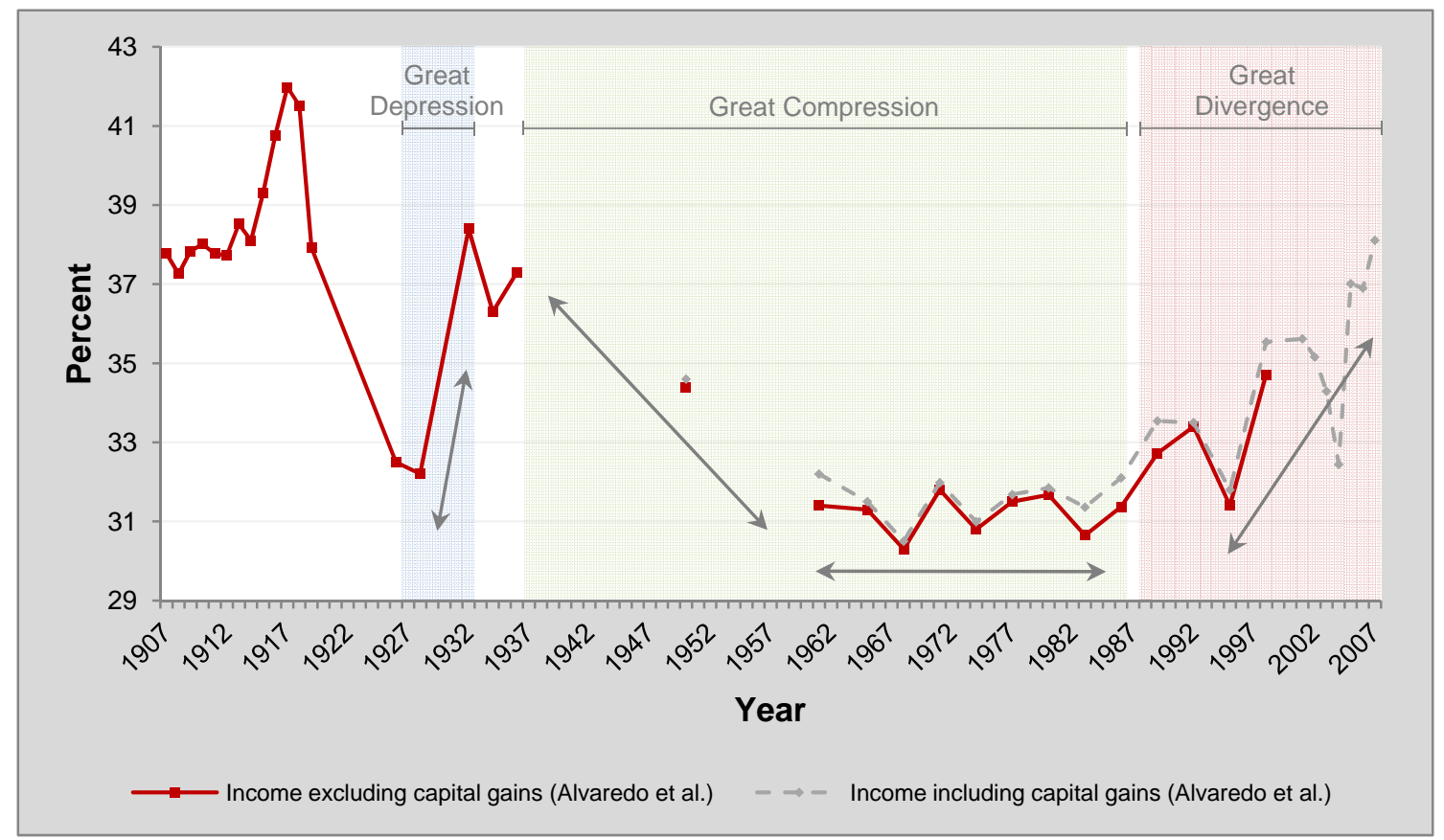

Source: Alvaredo et al. 2012, Table Germany.

Figure 8 shows the evolution of the top decile income share in Germany from 1907 until 2007 and is basically an update of Figure 2. Based on income data including capital gains, it can be clearly seen that the top ten percent income share continued to grow over the past years. While the top decile income share accounted for 35.5 percent in 1998, it had increased to 38.1 percent in 2007 and thus approximately reached the level of 1936. Although the top ten percent income share has not yet reached its preWorld War I level, the development in Germany is still comparable to the evolution of high incomes in the United States where the top decile income share in 2007 had approximately reached its late 1920s level. Looking just at the top decile income share in the period from 1936 to 2007, the "bathtub” has indeed been completed in Germany.

Similar developments of income shares also hold for different income fractiles 
within the tenth decile (see Appendix B). However, since capital gains form a quite volatile income component for the highest income groups, a more detailed analysis of the data (excluding capital gains) conducted by Bach et al. (2009) can emphasize the dimension of the income share increases of the top income fractiles which have been occurring during the past years. As shown in Figure 9, only the ninth and the tenth decile saw a rise of their gross income shares between 1992 and $2005 .{ }^{10}$ Within the top ten percent, the share of each income group increased, but there have been substantial differences: While the income share of the top one percent rose by just 20.8 percent from 1992 to 2005, the income ratio of the top 0.0001 percent grew by 181.3 percent.

Figure 9: Growth of income shares across different income fractiles in Germany, 1995-2005

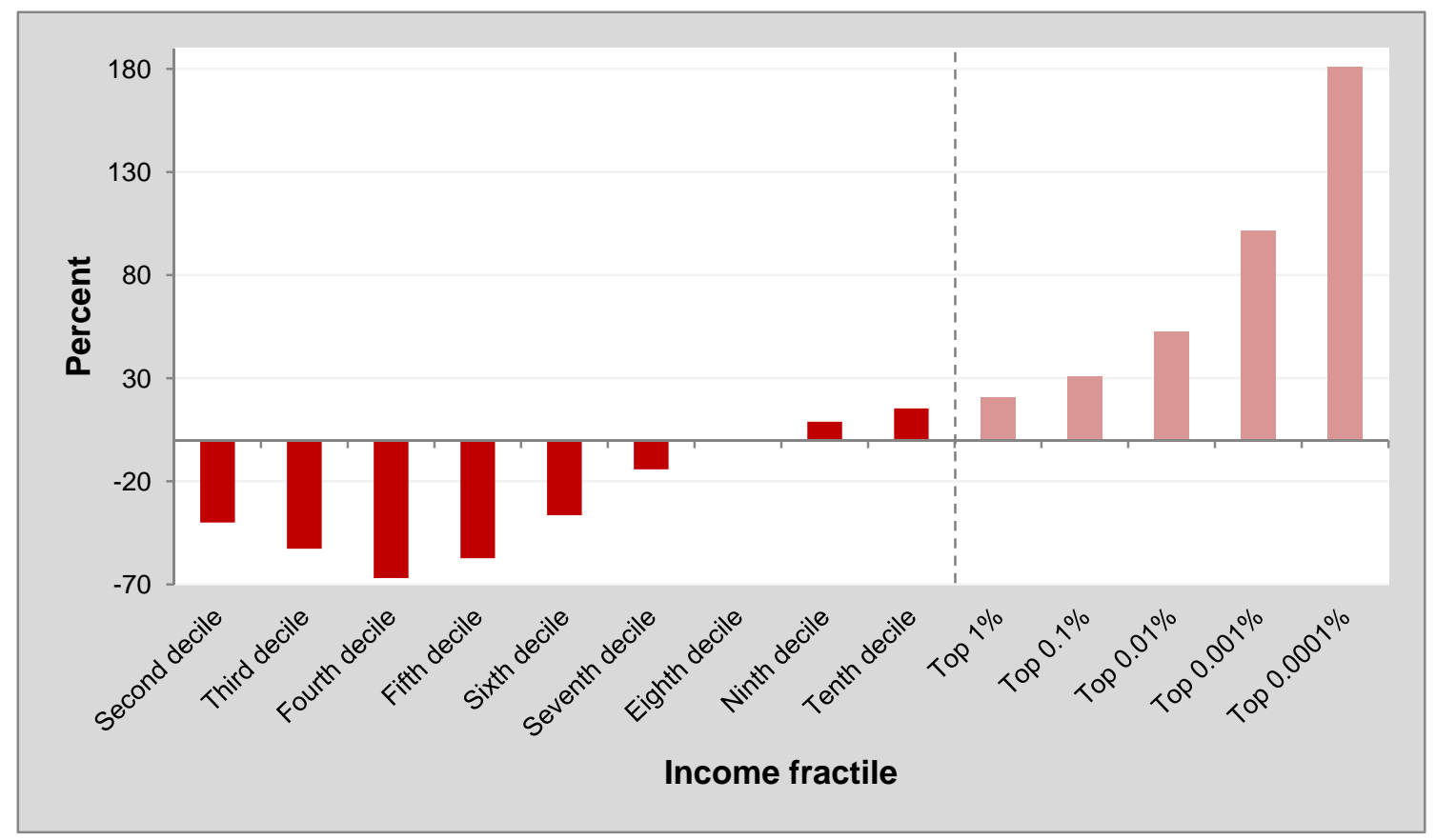

Source: Bach et al. 2009, Table 3; own calculations.

\subsection{From rentier to "working rich" income: The composition of top incomes}

In the United States, the composition of high incomes has changed significantly over the past years. While top incomes primarily consisted of capital income at the beginning

10 The first decile is not included since its gross market income is negative (cf. Bach et al. 2009, Table 3). 
of the twentieth century, this structure has changed in recent years. As shown in Figure 10 on the example of the top 0.1 percent of the distribution, capital income dominated the picture until the beginning of World War II but has become less important in the years thereafter. ${ }^{11}$ Since 1975 , the share of salaries has been exceeding the share of capital income within the top 0.1 percent and has been representing the largest income component (when capital gains are excluded). Since 1988, also the share of business income has been surpassing the share of capital income (see Figure C.1). ${ }^{12}$

Figure 10: Top 0.1 percent income share and composition in the United States, 1916-2010

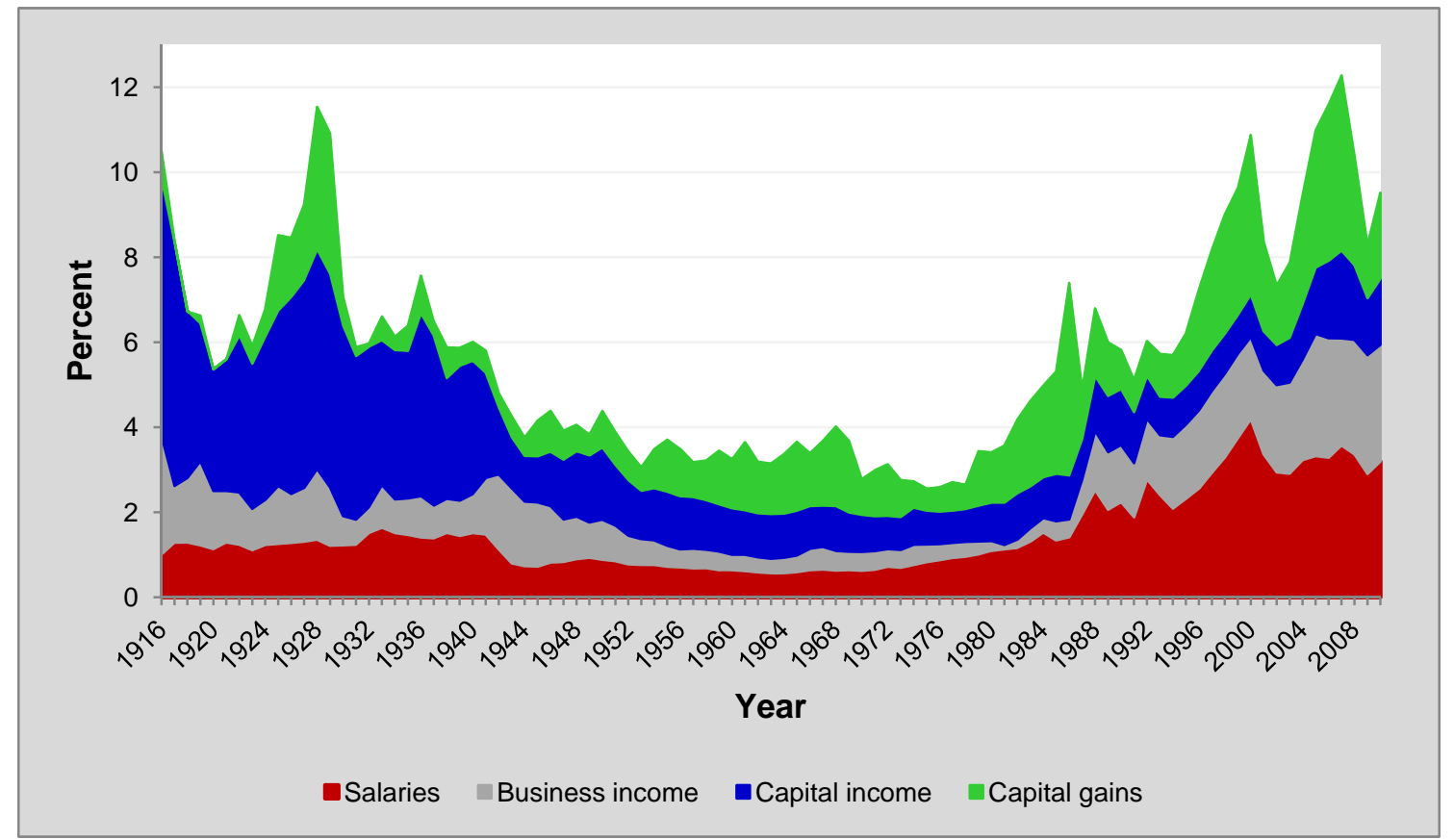

Source: Alvaredo et al. 2012, Table United States.

In 2010, salaries accounted for almost 43 percent of total income excluding capital gains within the top 0.1 percent of the distribution, business income made up about 37 percent, and the capital income share amounted to roughly 21 percent. Eight decades before, the shares of salaries, business income, and capital income accounted for 19 percent, eleven percent, and 70 percent. Piketty and Saez state that the weight of

11 According to Piketty and Saz, the decrease of capital income shares within the top income groups over the twentieth century is partly due to the implementation of progressive income taxation (cf. Piketty/ Saez 2007, pp. 156).

12 Following Atkinson, Piketty, and Saez, salaries include wages and salaries, bonuses, profits from exercised stock options, and pensions. Business income consists of self-employment income, partnership income, and small business income. Capital income includes interest income, dividends, rents, and other investment income (cf. Atkinson/Piketty/Saez 2011, p. 8; Saez 2005, p. 404). 
wages and salaries has increased across all income fractiles within the top decile over the past years, especially since the early 1970s (cf. Piketty/Saez 2007, pp. 150). ${ }^{13}$ While the decrease of top income shares during the Second World War was therefore mainly due to a decline in capital income, the increase in high income shares which has been occurring since the early 1980s is primarily attributable to a rise in employment income (cf. Piketty/Saez 2007, pp. 150; OECD 2011a, pp. 347). Referring to the United States Piketty and Saez (2007, p. 152) conclude: “Thus, today, the 'working rich’ [...] have overtaken the 'coupon-clipping rentiers'.”

Following the evolution in the United States, the question ultimately arises of whether a similar shift in the top incomes composition from capital income to wages and salaries has also occurred in Germany. Is the recent rise in German high income shares mainly attributable to an increase in employment income, too?

Although data available for Germany are quite sparse compared to the US, it can still be shown that wages and salaries have become more important across top income groups over the past years. The German developments are indeed much less pronounced than the ones in the United States, maybe also because the share of wages across top income groups is in general relatively small compared to other countries like the US or France (cf. Bach et al. 2009, p. 319). However, German wage shares at the top of the income distribution are yet higher today than at the beginning of the twentieth century, which can be confirmed by Figure 11. For instance, while wages and salaries accounted for approximately 78 percent for the bottom five percent of the top decile prior to World War II in 1936, they made up about 90 percent in 1998. Simultaneously, the share of self-employment income also increased, whereas the shares of both busi-

13 Piketty and Saez assume that due to the decline of progressive taxation since the beginning of the 1980 s in the United States, capital incomes could regain relative importance across top income fractiles during the next years (cf. Piketty/Saez 2007, p. 167). 
ness income and capital income decreased. ${ }^{14}$ Similar developments hold for all other fractiles within the top ten percent of the distribution.

Figure 11: Sources of income across top income fractiles in Germany, 1936 and 1998

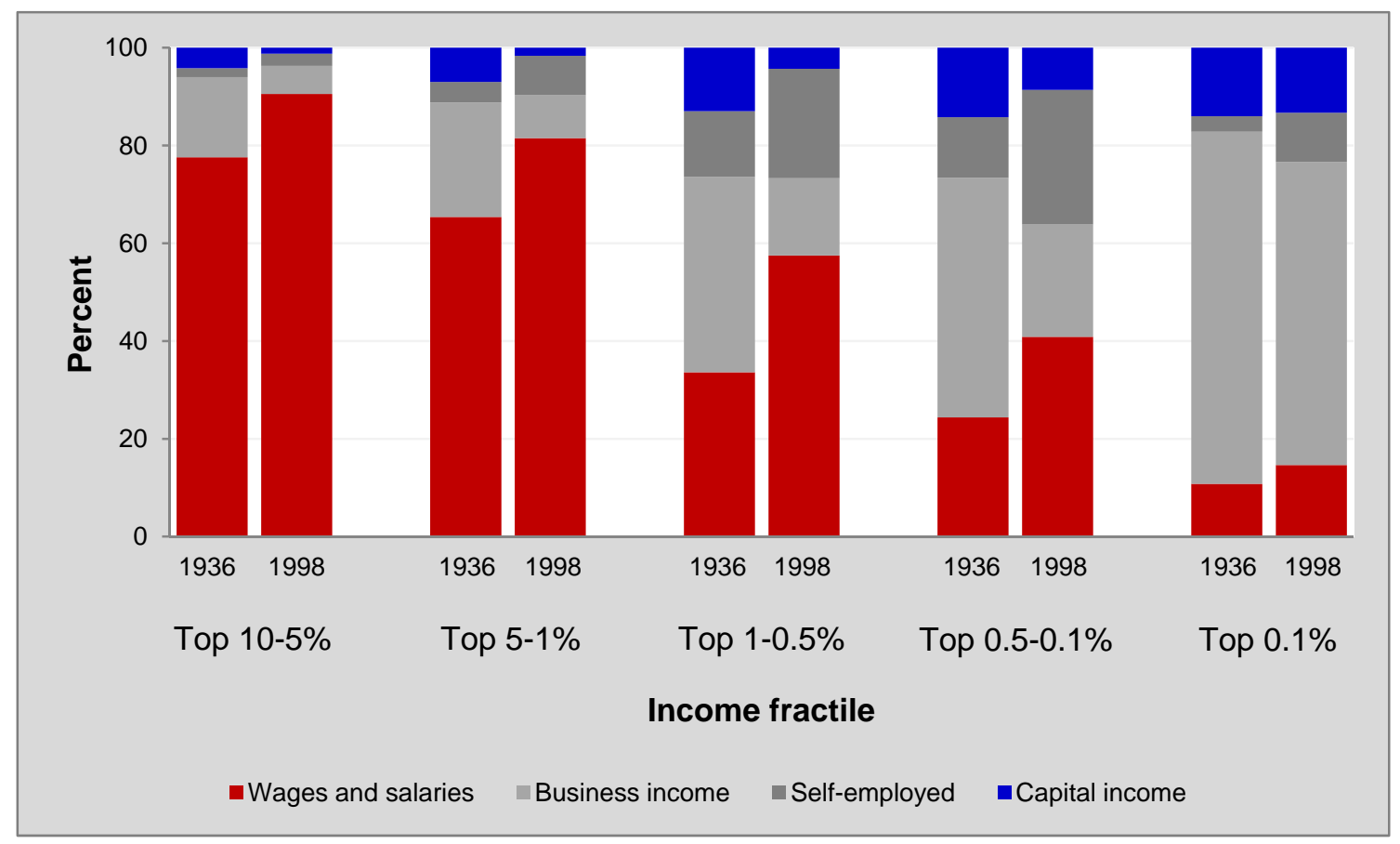

Source: Dell 2007, pp. 382.

Although direct comparability with data by Dell (2007) is limited, it is still reasonable to also take a look at some calculations by Bach et al. (2009) which allow for an analysis of top wage shares during recent years. ${ }^{15}$ As shown on the example of the top 0.1 percent of the distribution in Figure 12, despite a decline from 2001 to 2005, the wage share increased substantially between 1992 and 2005. While the wage portion of the top 0.1 percent accounted for 15 percent in 1992, it had risen to approximately 21 percent in 2005.

It should be noted that other than in the United States, wages and salaries still

\footnotetext{
14 'It should be noted here that German tax law registers as 'business income' (Einkünfte aus dem Gewerbebetrieb) incomes that would, for example in France, be recorded as capital income. This phenomenon still exists today and is related to the fact that public corporations (Aktiengesellschaften) which pay dividends which are in turn taxed under the category 'capital income' was until recently quite rare in Germany. Other legal forms for societies (Kommanditgesellschaft or Offene Handelsgesellschaft) seem to have been much more widespread and even encouraged by corporate and business tax law. [...] Thus top income shares decline in the first half of the century is a capital income phenomenon [...].” (Dell 2007, p. 381).

15 The issue of combining data from several sources is discussed in Appendix A.2.
} 
do not make up the majority of top 0.1 percent incomes. However, according to Bach et al. (2009) only the wage income share increased between 1992 and 2003, whereas all other income components (business income ${ }^{16}$, capital income) saw a decline in their relative shares within the top 0.1 percent income group (cf. Bach et al. 2009, p. 318). These developments also hold for almost all other income fractiles within the top decile, and "this pattern parallels a recent development in the U.S. where increasing income [...] [dispersion] was apparently driven by an increasing share of wage income in the top percentile of the distribution.” (Bach et al. 2009, p. 319)

Figure 12: Wage share within the top 0.1 percent in Germany, 1992-2005

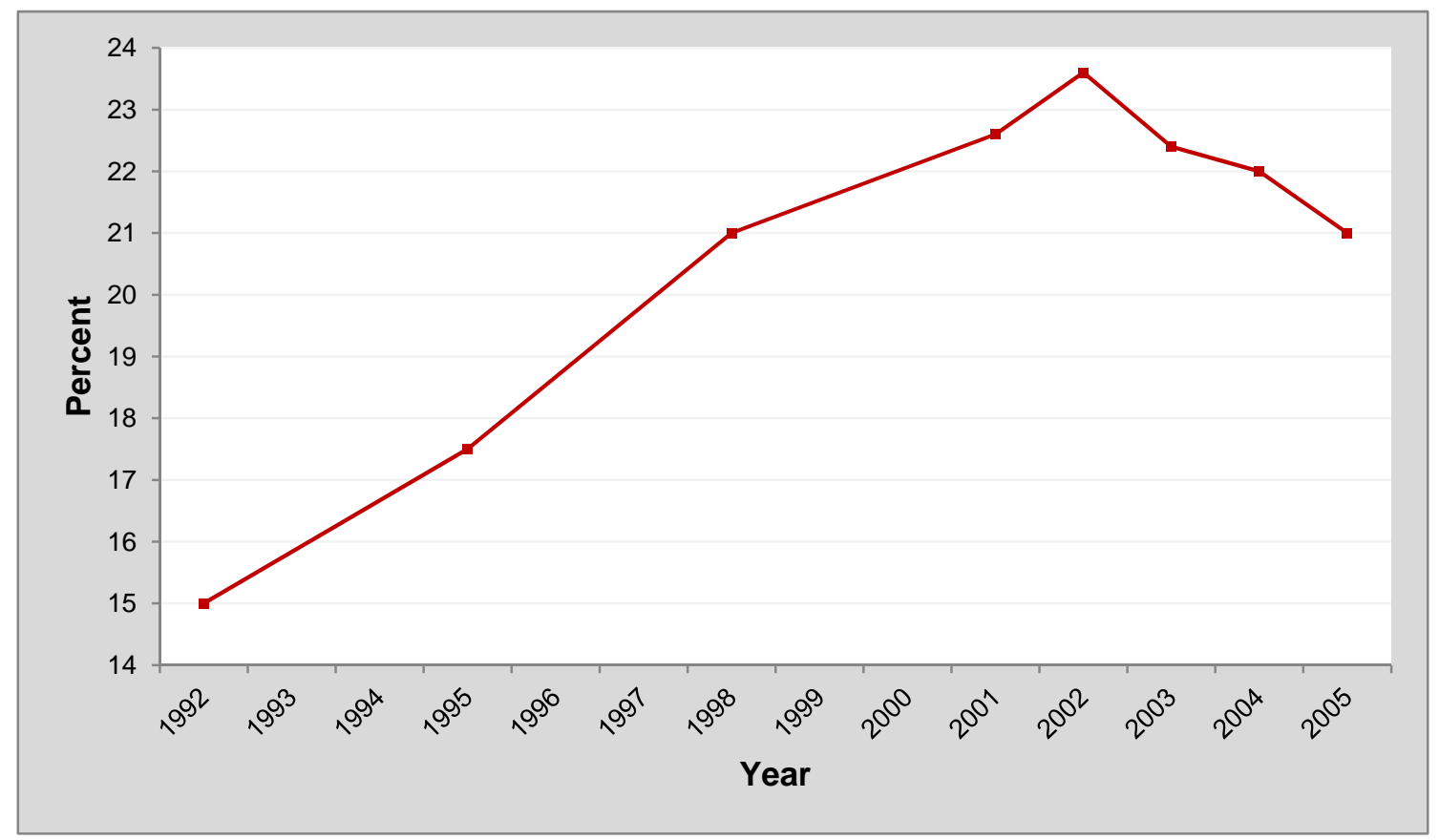

Source: Bach et al. 2009, p. 320; 2003-2005: unpublished update by Bach.

To sum up, even if the development is not as pronounced as in the US also in Germany the importance of labor income compared to rentier income within the top income groups tended to increase over the last decades. Thus, it seems not too daring to conclude that it was the "working rich" that had a considerable impact on the rise in income divergence in Germany.

16 According to Bach et al. (2009), business income includes “[...] income from agriculture and forestry, from unincorporated business enterprise and from self-employment activities [...].” (Bach et al. 2009, p. 309). 


\section{Factors behind the evolution of top labor incomes}

\subsection{The influence of top management compensation}

As shown in the previous section, it was the relative increase of employment (and business) income rather than capital income that is mainly responsible for the rise in the top income shares in the USA as well as in Germany. This finding might come as a surprise, for when analyzing functional income distribution we observe a significant increase in the profit share in total income over the last twenty years in both countries as well as in other advanced economies (cf. Krämer 2011). And since wealth distribution is even more concentrated than income distribution (cf. Hauser/Krämer 2011, pp. 48) one would expect that the increase in the top income shares at the personal level could be explained to a large extent by rising flows of capital income. ${ }^{17}$ However, at least at the very top this was not the case as we have seen in the previous section. Therefore the question arises of how to explain the large gains of the top income earners that occurred in the US and Germany recently.

Some argue that the increase in overall income divergence in the United States between the beginning of the 1970s and early 1990s was mainly due to de-unionization and the decline in the real value of the minimum wage (cf. DiNardo et al. 1996). But when looking at top incomes, it is more important to consider that there is a concentration of certain occupations in the top income groups. A study for the USA found that executives, managers, supervisors as well as financial professionals play an important role in the share of the top 0.1 percent group (cf. Bakija et al. 2010; quoted after OECD 2011a, p. 351). According to their calculation during 1979 and 2005, more than two thirds of the increase in the share of the top 0.1 percent group went to high earning managers and financial professionals. Another study for the UK came to a similar pic-

\footnotetext{
17 The links between functional and personal income distributions in Germany have been analyzed by
} Adler and Schmid (2011) recently. 
ture: Although people working in the financial sector comprised only 3.2 percent of all taxpayers in 2007/2008, their share in the top 1 percent income earners made up 21.2 percent; and while tax payers engaged in real estate, renting and other business activities contributed 28.5 percent to the top 1 percent income bracket they represented only 13 percent of all British taxpayers (cf. Survey of Personal Incomes 2007-08; quoted after OECD 2011a, p. 351). We can note that top incomes are earned in a large part by high ranking managers (especially executives) and financial professionals. ${ }^{18}$ Due to the importance of top managers and executives in particular, it seems worthwhile to take a closer look at factors determining their earnings.

Published figures on the very high compensation of public companies' executives and in particular their CEOs create a great deal of annoyance in public debates in Germany. ${ }^{19}$ On this occasion commentators regularly question the justification of their incomes. In contrast, defenders of high incomes of executives argue that these managers bear high responsibility for thousands of jobs and billions of annual revenue. Others simply accuse their critics of just being envious while there are those who merely claim that it would be a fruitless attempt to justify mega incomes. ${ }^{20}$ The objective of the next sections is to check whether there are any explanations for the high level incomes that are paid out to these professions which are supported by economic theory.

\subsection{Why the standard approach is not suitable to explain top incomes}

According to the standard textbook theory of income distribution, the reward for each

18 It is important to note that tax authorities as well as federal statistical agencies define all the income of high-ranking executives as being labor income. This includes even performance-related pay instruments, like stock options, which are oriented towards the company's share price development.

19 According to the German weekly Die Zeit (May 16, 2012), the CEO of Volkswagen, Martin Winterkorn, was last year's top earner among German CEOs with an annual income of 16.6 million Euros. He was followed by Deutsche Bank’s Josef Ackermann who received about 9.4 million Euros.

20 Josef Ackermann, chief of Deutsche Bank until May 2012, said in an interview with the German weekly Stern (October 29, 2010) that he cannot give reasons for the size of his income (cf. http://www.stern.de/wirtschaft/news/josef-ackermann-mein-gehalt-ist-nicht-zu-begruenden1618688.html, accessed on April 9, 2012). 
factor of production is based on its marginal productivity. Labor endowed with physical or human capital is more productive than labor without it. In other words, people with higher qualifications usually enjoy a premium for their better competence. Following this approach, much of the earnings dispersion that occurred over the last decades has been explained by an increase in skill premia of the better educated (cf. OECD 2011a). Skill-biased technological change - and to some extent international trade as well - is assumed to raise the relative demand for qualified labor and exert pressure on wages for low qualified workers. The observed wage dispersion in Germany, a country that is relatively open to international trade, could therefore be viewed as a story of rising skill premia that allow the best educated of the workforce to reap the fruits of technological change and globalization.

This approach suffers three main shortcomings. First, it cannot explain why there are so big differences within the top decile or even the top percentile - a phenomenon our data analysis has clearly revealed for the US and for Germany. As we have seen, the smaller the income fraction is defined and the closer to the very top, the larger is the positive divergence from average income growth. Since it is obvious that within the top decile the fraction of unqualified workers is probably rather low, the large disparities within this subgroup cannot be fully grounded on diverging qualifications. We even observe large differences in earnings of individual people of the same profession, which is another counter argument against traditional explanations of growing inequality that are based mainly on skill levels and premia. Top incomes are, thus, not solely affected by general trends (e.g. a higher relative demand for skilled labor), but rather other forces are at work that accentuate income divergence.

Second, we have found that income disparity has been growing over time. So from an explanation referring solely to rising demand for higher qualification it follows that also skill premia must have been rising steadily. But, is that reasonable to assume? 
Growing skill premia would go hand in hand with an increasing wage differential between low and high qualified labor, making it more and more attractive to invest in human capital formation. If we assume that in the long run the US and the German education system reacts accordingly, both economies will be able to adjust to the growing demand in qualified labor; sooner or later the increase in that demand will be matched by additional supply of skilled labor. If in the long run "the race between technology and education” (Atkinson 2008, ch. 2) is a tied game, then the wage differential between the skilled and the unskilled will be constant and not be growing, as has been suggested above. However, a constant wage differential has a noteworthy consequence for the development of income shares: As one would rightly expect, the income share of, say, the lowest quintile will fall, with a shift towards a higher proportion of skilled labor in the total workforce. However, as Atkinson (2008, pp. 12) has demonstrated in a rather simple numerical example, the share of the top decile will shrink as well. The reason is that the shift towards skilled labor will raise the average wage and, if the wage differential remains constant, the top quintile will see its income decreasing relative to the average. In contrast, we do not find a drop but a growth of the top quintile in reality. Hence, Atkinson (2008, p. 13) concludes that the skill premium story "cannot explain a situation where there are increasing shares of top earners.”

A third argument against a marginal productivity based explanation of top incomes is a rather practical one. It raises the question of how to measure an individual's marginal productivity in today's world that is characterized by a high degree of (international) labor division driven by increasing fragmentation of different stages of production. An empirical assessment of the marginal productivity of a single worker might be possible in a Robinson Crusoe world - and it will even be easier before the arrival of Friday. As soon as Robinson Crusoe and Friday figure out the benefits of the division of labor and the positive productivity effects resulting from teamwork, the accurate meas- 
urement of the individual value contribution of each of them becomes rather difficult in practice. This holds true for many industries today where the value chain gets split in more and more components. ${ }^{21}$ Consequently, measuring marginal productivity in many cases in the real world makes sense only when applied to a team but not to the individual. The same is true when attempting to measure marginal productivity of CEOs and top executives. Also their productivity depends to a large extent on the joint work with their staff. Thus, this is an additional argument why it makes no sense to derive an explanation (or "justification”) for the rising remuneration of top executives from the marginal productivity approach.

Alternative approaches have been developed to explain top labor incomes. Three of them shall be outlined briefly in what follows. The first two have some links to sports; the last one follows considerations from psychology and sociology.

\subsection{Should top executives be treated as superstars?}

A theory that is widely used in labor economics today to explain extremely high incomes is the theory of superstars. This approach is usually applied to professions in which inherent talent plays an eminent role, like in sports, arts, showbiz et cetera. In economics talent is regarded as a non-producible asset; hence, the treatment of this "factor of production” bears some similarity to the treatment of the production factor land in economics. To that extent, the theory of superstars borrows some thoughts from classical rent theory: similar to Ricardo’s theory of rent, in which land can be ordered according to its fertility, professionals in sports, music, literature, and so on are ranked subject to their proficiencies. And, since consumers have only limited time to watch movies,

21 Referring to current developments in service trade, Grossman and Rossi-Hansberg (2008) state that due to deeper fragmentation it is now primarily "tasks" that are traded internationally rather than final outputs. 
attend theatre performances, read novels and so on, they tend to prefer the best athlete, actor, musician et cetera. The best one will therefore earn much more than all the others, even if - and this is important - they are performing only slightly less well. A "winnertake-all principle” prevails when only the best one in his or her field acquires a major slice from the cake. The earnings of superstars are not determined by their absolute abilities (productivity) but rather in comparison to other competitors in their profession. Relative rather than absolute skills are key! Recently, globalization in combination with advances in communication techniques let the income of a new type of "global superstars” explode. Thanks to satellite TV and the internet today's media stars are able to reach a much larger audience than before. At the same time they can even capture a big share of income from former "regional superstars" which will now be superseded and ranked only second best.

How helpful is the superstar theory to explain the huge income hikes we have seen for top executives over the last decades? Surely, many executives will sympathize with the notion of being called a superstar. One must cast doubts, however, whether top executives can be ranked unambiguously according to their managerial skills. There is a long list of literature covering the problem of how to measure skill, performance and success of managers (cf. Martocchio 2011, pp. 65). Moreover, unlike in sports where championship systems with more or less clear rules of the game ensure that most of the time the best will reach the top, this is not at all so in management as many examples of inept executives and cases of outlandish mismanagement have demonstrated. Over and above many executives simply owe their job to networks in which relationships rather than proven skills can be far more important. Having dealings with influential people has often been a major success factor for business people on their way to the top. The theory of superstars seems therefore ill-suited to explain executive compensation. 


\subsection{Tournament theory: Executive compensation as prize money}

Another way of explaining top incomes in management is based on the so-called tournament theory, as it parallels the structure of success and pay in sports tournaments (cf. Lazear/Rosen 1981). The basic idea rests on the argument that having high pay differentials between different managerial ranks can be an effective method to maximize productivity of the whole system. Like in a tennis tournament where the differences between the best players are only marginal, it is assumed that also the qualifications of top managers differ only slightly. The differences in rewards are, however, substantial as tennis players (managers) advance to the next tournament (hierarchy) level.

In sports it sometimes depends on good fortune to become a champion; the same might be true in management as well. Yet, after all in management it is not crucial that really the best will grab the higher management positions. If there are only small differences in managerial skills among the competing executives, but huge differences in compensation depending on the management rank, the incentives for the individual to struggle hard in order to climb up the career ladder will ensure a maximization of overall productivity.

Also in management there are fewer positions at higher levels, and the ultimate prize is being promoted to become CEO. In major tennis tournaments the victor is usually awarded prize money double the sum of the defeated men, although they play tennis on about the same level. The primary reason for high CEO incomes is, therefore, not to provide an incentive for the CEO to perform well, but to give those at lower levels an incentive to work hard. Whether the level of compensation in the respective ranks of the hierarchy matches the individual's true ability is not decisive. It is more important that the substantial income gain the individual can achieve when he or she steps up the ladder is assumed to optimize the whole system. According to this approach, the compensation system for executives in corporations is designed in a way to ensure that every- 
one performs to his or her maximum so that the productivity of the whole system increases. $^{22}$

How much does the tournament theory help to explain the substantial increase of top management and executive incomes then? Although the basic principle has at least some explanatory power compared to the approaches discussed above, it cannot explain the core of the story. First, it is difficult to argue how big the gap between the different levels of the hierarchy has to be to make the system function best. Was it really necessary to more-than-double CEO compensation in the US relative to other members of the board of management over the last decades to optimize corporate performance of US companies? How about the psychological effect of the immense salary hikes and its medium term impact on society? The tournament theory cannot answer these questions. The main objection, however, regards the relation of the total amount of top executive compensation to the earnings of all other employees in a corporation. Since the tournament theory refers to the pay of an individual member of the top management relative to other members of the top management, it is unclear why the median income of the group of executives has rocketed so strongly in the last decades. This approach, too, cannot carry forward the analysis of the steep absolute and relative increase of top incomes in highest management positions we reported above. At this point explanations offering interdisciplinary perspectives might be more promising.

\subsection{Norms, social comparison, and rent seeking}

Atkinson (2008, pp. 72) reminds us of psychological and sociological approaches to explain earnings dispersion and makes a case for taking them into closer consideration. ${ }^{23}$ He emphasizes the importance of pay norms in determining (high) salaries (cf.

\footnotetext{
22 This compensation scheme could therefore also be called a carrot-and-donkey approach to increase overall corporate performance.

23 Phelps Brown (1977) in his influential book “The Inequality of Pay” isolates economic approaches to
} 
Atkinson 2001). Breaking the existing pay norm implies to risk the loss of someone's reputation. However, pay norms can change, and the very high executive remuneration seems to be more acceptable today than it used to be. Bebchuk/Fried (2004) implicitly refer to these kinds of norms when they stress the impact of what they call "outrage" constraints: constraints that are based on public reactions to extreme executive compensation. Piketty and Saez (2007) state that during the past years the rise in salaries at the top of the distribution has primarily been caused by a shift in social standards: "The marginal product of top executives in large corporations is notoriously difficult to estimate, and executive pay is probably determined to a significant extent by herd behavior. Changing social norms regarding inequality and the acceptability of very high wages might partly explain the rise in US top wage shares observed since the 1970s.” (Piketty/Saez 2007, p. 165) Also, the increasing practice of granting stock-options to executives and lower-level employees can be hold partly responsible for the rise in high wages (cf. Hall/Murphy 2003; Piketty/Saez 2007, p. 163). ${ }^{24}$

In the US, executive compensation is usually determined by so-called compensation committees. In Germany this duty used to be undertaken by the "Aufsichtsrat" (supervisory board) alone, but more and more German stock corporations adopted this type of council in the last years from the Anglo-Saxon system. However, outside directors on supervisory boards and compensation committees mostly include executives and CEOs from other corporations. According to the theory of social comparison this system has a major impact on the level of income granted to executives. Members of compensation committees were observed to base their pay decisions or pay recommendations on their own earnings, since they compare themselves to similar individuals (cf. O'Reilly et al. 1988). Their judgment about the appropriate pay for colleagues on an tive rather than a complementary explanatory power.

24 As mentioned already above exercised stock-options are registered as wages and salaries on tax declarations (cf. Piketty/Saez 2007, p. 163). 
equal footing depends strongly on their own income, thereby following a common heuristic in decision making, known as the anchoring-effect. As O'Reilly et al. (1988) have shown the sum that members of these bodies had in their own jobs as executives is quite a good indicator of their decision about the level of earnings of other executives. Although they found a strong correlation here, there was only a weak nexus between executive compensation and overall corporate performance. ${ }^{25}$ In a more recent study, O'Reilly and Main (2007, p. 16) found that “on the average, for every $\$ 1,000$ more in fees that is given to the chair of the compensation committee, the cash compensation of the CEO is $\$ 1,746$ higher.” This finding indicates a major agency problem, since it is usually assumed that members of the supervisory board first and foremost advocate the interest of the shareholders (cf. Eisenhardt 1989). Obviously this is not the whole story. The present framework which gives executives control of their own pay-setting process might therefore indicate a severe malfunctioning of the current corporate governance framework (cf. Tosi/Gomez-Meija 1989; Bebchuk/Fried 2003).

In the end, the true reasons behind the rising top (executives) incomes might be found when analyzing the behavior of an influential group of rent seeking decisionmakers (cf. Krueger 1974). As Bebchuk/Fried (2004) argued, the high levels of executive compensation have their roots in managerial rent-seeking. If this were true, the rent seeking individuals of today are not classical rentiers, living on land and capital property, but have to be regarded as a very special type of modern privileged laborers.

\section{Final remarks}

Inspired by the significant increase of top income shares in the United States since the early 1980s, the present paper examined the evolution of high incomes in Germany over

\footnotetext{
25 See the current discussion on "pay without performance” in the USA which was initiated by the samenamed book by Bebchuk and Fried (2004).
} 
the past decades. Unlike the developments in the US, a rise in German top income shares did not appear until the late 1980s/mid-1990s, and it was quite moderate then. However, this increase has continued during recent years, so that in 2007 the top decile gross income share approximately reached its level of 1936 again. Therefore, the statement by Atkinson and Piketty regarding the absence of a U- or "bathtub"-shaped pattern of top income shares in Continental Europe has to be revised for Germany. Similar to the developments in the United States (but certainly less pronounced), this rise in high income shares was not driven by a relative increase in capital income but rather by a relative increase in wages and salaries at the top of the distribution. In search of any theoretical explanation for the growing income levels of especially top managers and financial professionals, the present paper revealed that the standard theory of personal income distribution based on marginal productivity is not applicable in this case. While other approaches such as the theory of superstars or the tournament theory were also considered of limited suitability to explain the high incomes of top managers and executives, the insights provided by the theory of social comparison in combination with the assumption of managerial rent seeking behavior could be helpful in explaining the increasing absolute and relative remuneration at the top.

The present paper addressed some general developments in personal income distribution with a special focus on top incomes in Germany. However, one should look beyond the main finding - that is to say an increase in overall income dispersion. Ultimately, the prime reason to deal with that topic is that rising income differences are critical in a social and economic sense. When the benefits that stem from economic growth are spread unevenly across the population, when incomes at the bottom of the distribution decline whereas those at the top increase significantly, then "[...] the structures that hold our societies together [are weakened] and [...] our ability to move forward [is threatened].” (Gurría 2011; quoted after OECD 2011b, p. 3) Increasing income disper- 
sion jeopardizes social cohesion, and the initial effects of this phenomenon can currently be observed on the example of the Occupy Movements around the world. Furthermore, rising income disparities are said to inhibit long-term economic growth. In a recent study, the International Monetary Fund identifies income dispersion as a most important factor which is inversely correlated with economic growth duration (cf. Berg/Ostry 2011). From a social and economic point of view it is thus necessary to question the sustainability of the recent developments of German top income shares outlined in the present paper. 


\section{Appendix A: Data sources and methods}

\section{A.1 Summary of sources used}

Table A.1: Data sources for Germany used in the present paper

\begin{tabular}{|c|c|c|c|c|c|}
\hline Source & Data basis & Years covered & Income definition & Unit of analysis & $\begin{array}{l}\text { Handling of } \\
\text { capital gains }\end{array}$ \\
\hline $\begin{array}{c}\text { Alvaredo et al. (2012) } \\
\text { Dell (2007) } \\
\text { (The World Top Incomes } \\
\text { Database) }\end{array}$ & Income tax records & $\begin{array}{l}1891-2007 \\
\text { (with breaks in } \\
\text { some years) }\end{array}$ & $\begin{array}{l}\text { "[...] Total net incomes (i.e. minus } \\
\text { expenses necessarily incurred in } \\
\text { obtaining these incomes, the so- } \\
\text { called Werbungskosten), before } \\
\text { social transfers and taxes, but after } \\
\text { employers' payroll taxes and corpo- } \\
\text { rate income tax." } \\
\text { (Dell 2007, p. 369) }\end{array}$ & $\begin{array}{c}\text { Family } \\
\text { (married couples } \\
\text { and singles aged } \\
20 \text { or older) }\end{array}$ & $\begin{array}{c}\text { 1891-1936/1938 } \\
\text { and 1950-1998: } \\
\text { Capital gains excluded } \\
\text { 1950-2007: } \\
\text { Capital gains included } \\
\text { (with breaks in some } \\
\text { years) }\end{array}$ \\
\hline Bach et al. $(2009,2011)$ & $\begin{array}{l}\text { Income tax records } \\
\text { in combination with the } \\
\text { German Socio- } \\
\text { Economic Panel Study } \\
\text { (SOEP Study) }\end{array}$ & $1992-2005$ & $\begin{array}{c}\text { Gross market income, consisting of } \\
\text { wage income, business income, } \\
\text { and capital income }\end{array}$ & $\begin{array}{c}\text { Individual } \\
\text { (aged } 20 \text { or older) }\end{array}$ & Capital gains excluded \\
\hline $\begin{array}{c}\text { German Socio- } \\
\text { Economic Panel Study } \\
\text { (SOEP Study) (2010) } \\
\text { Grabka (2011) } \\
\text { OECD }(2012 a, 2012 b)\end{array}$ & $\begin{array}{c}\text { Annual survey of private } \\
\text { households living in } \\
\text { Germany }\end{array}$ & 1984-2010 & $\begin{array}{l}\text { Equivalent annual net household } \\
\text { income } \\
\text { (modified OECD equivalence scale) }\end{array}$ & $\begin{array}{l}\text { People in private } \\
\text { households }\end{array}$ & Capital gains excluded \\
\hline
\end{tabular}

Note: The information provided in Table A.1 only refers to the data for Germany used in the present paper. All other sources are explicitly indicated in the text. 
As can be seen from Table A.1, the data sources used in the present paper differ in characteristics such as the underlying income definition or the unit of analysis. Although direct comparability is thus restricted, it should be noted that the general development of the various income components does not vary significantly.

\section{A.2 Dealing with data inconsistency}

The figures used in section 3 have primarily been obtained from The World Top Incomes Database by Alvaredo, Atkinson, Piketty, and Saez, a data set which contains long-run information on top incomes for 26 countries. With discontinuities in some years, the series for Germany covers the period from 1891 to $2007 .{ }^{26}$ In general, The World Top Incomes Database provides income data both excluding and including capital gains. ${ }^{27}$ While “[... capital gains are not an annual flow of income [...] and form a very volatile component of income with large aggregate variations from year to year depending on stock price variations” (Piketty/Saez 2007, p. 144), income excluding capital gains is less dependent on current developments on fluctuating capital markets. However, German income data excluding capital gains are "only” available for the years up to $1936 / 1938$ and from 1950 to 1998 , whereas income data including capital gains can be obtained for the period between 1950 and 2007. The problem consequently arises as how to deal with the fact that latest high income data from 1998 to 2007 include capital gains.

One option to avoid this issue is to additionally use data from other studies and reports. For Germany, Bach, Corneo, and Steiner recently published calculations on the evolution of top incomes excluding capital gains for the period between 1992 and 2005.

\footnotetext{
26 Within The World Top Incomes Database, the data for Germany have been calculated by Fabien Dell (cf. Dell 2007).

27 Realized capital gains occur when assets are sold at a higher price than the buying price. "Individuals have flexibility in the timing of asset sales and capital gains realizations.” (Saez 2012a, p. 29).
} 
While the figures presented in The World Top Incomes Database allow the analysis of high incomes up to the top 0.01 percent of the distribution, the data calculated by Bach et al. (2009, 2011) have the advantage that they can be used to even study developments within the top 0.001 percent and the top 0.0001 percent. It should be noted, however, that the two series cannot be fully matched since Bach et al. use a slightly different approach than Alvaredo et al. (see Table A.1). Although direct comparability is restricted, it is still reasonable to chain the two data sets in a few cases, especially for analyses within the highest income groups for which capital gains form a quite significant (and volatile) income component. As can be seen from the overlapping values in Figures B.4 and B.6, differences between the two data sources are not excessively large, so it can be assumed that the data calculated by Bach et al. $(2009,2011)$ are a fairly realistic update of the figures determined by Alvaredo et al. (2012). Yet, one should be aware that the data derived from different sources.

An additional possibility is to just use income data including capital gains. Although capital gains certainly influence general income developments in some way, it is to be assumed that the integration of this income component still does not unduly distort the central message of the present paper. Saez, for instance, mainly refers to income data including capital gains in his latest study on the evolution of top incomes in the United States. Since for the US The World Top Incomes Database provides long-run income data both including and excluding capital gains, Saez is also able to contrast the two income components for the period from 1917 to 2010. His graphical comparison reveals that top income shares including capital gains are somewhat more volatile than income shares excluding capital gains. However, the general developments of both variables are very similar and they basically follow the same pattern (cf. Saez 2012b, pp. 7). For Germany, such a comparison can be conducted for the years from 1950 to 1998 . As can be seen from Figures 8 and B.1 to B.5, top income shares including and excluding 
capital gains evolved quite similarly, especially for the lower income fractiles within the top decile. Therefore, it is to be supposed that the use of income data including capital gains does not distort the general development of high incomes. ${ }^{28}$

To finally provide a broad overview of the evolution of German top incomes, the analysis in section 3 is not just based on a single data source. It rather comprises figures calculated by Alvaredo et al. (2012) and Bach et al. (2009, 2011) as well as income data both excluding and including capital gains.

\section{Appendix B: Top income shares in Germany, 1907-2007}

Figure B.1: The top 10-5 percent income share in Germany, 1907-2007

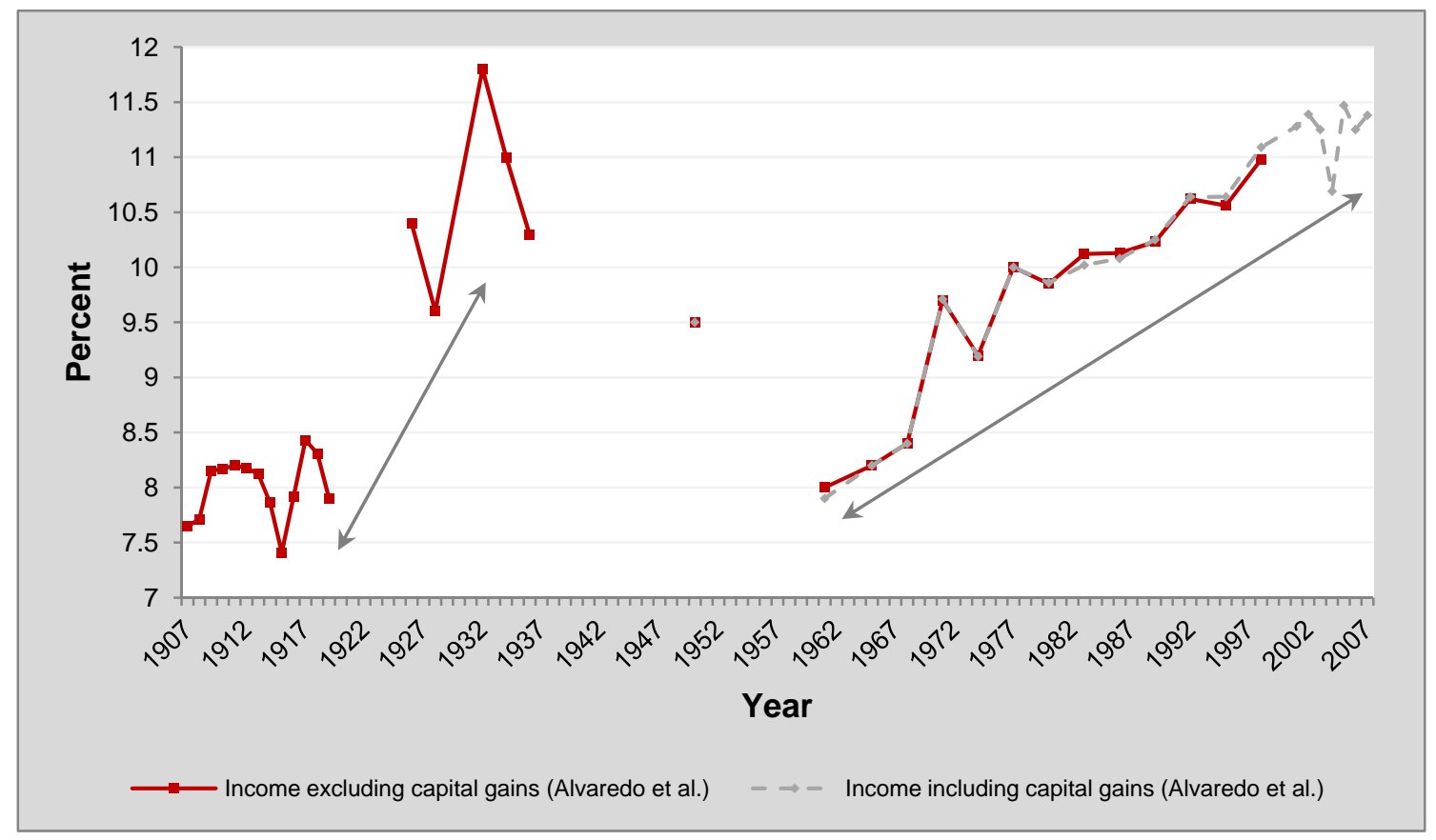

Source: Alvaredo et al. 2012, Table Germany.

28 According to Dell, realized capital gains “[...] become significant only in the top income groups [...] [(above the 99.5 percentile)]" (Dell 2005, p. 414). Saez mentions that “[...] series with and without capital gains are very similar over the long-run.” (Saez 2005, p. 404) 
Figure B.2: The top quintile income share in Germany, 1907-2007

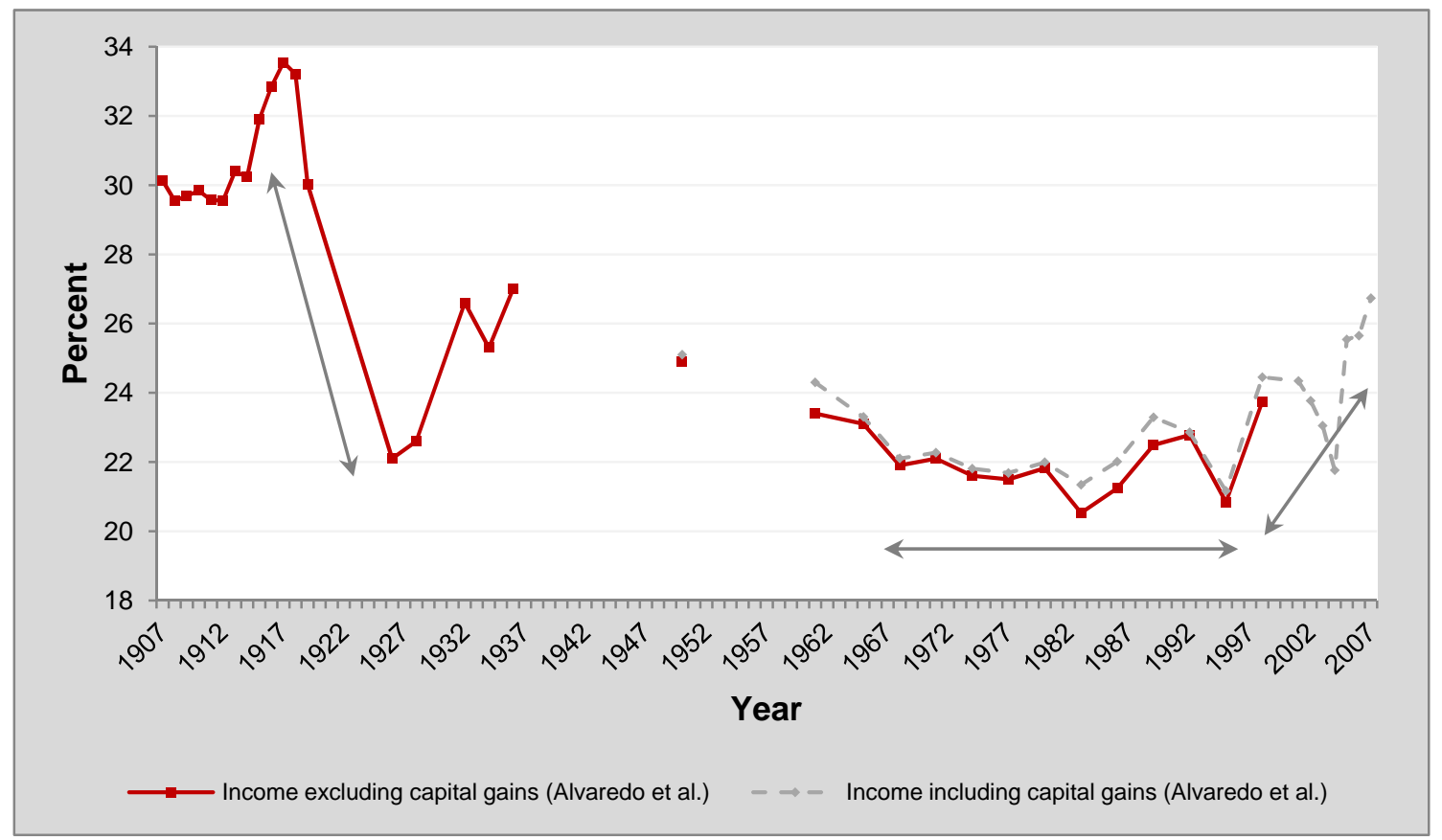

Source: Alvaredo et al. 2012, Table Germany.

Figure B.3: The top 5-1 percent income share in Germany, 1907-2007

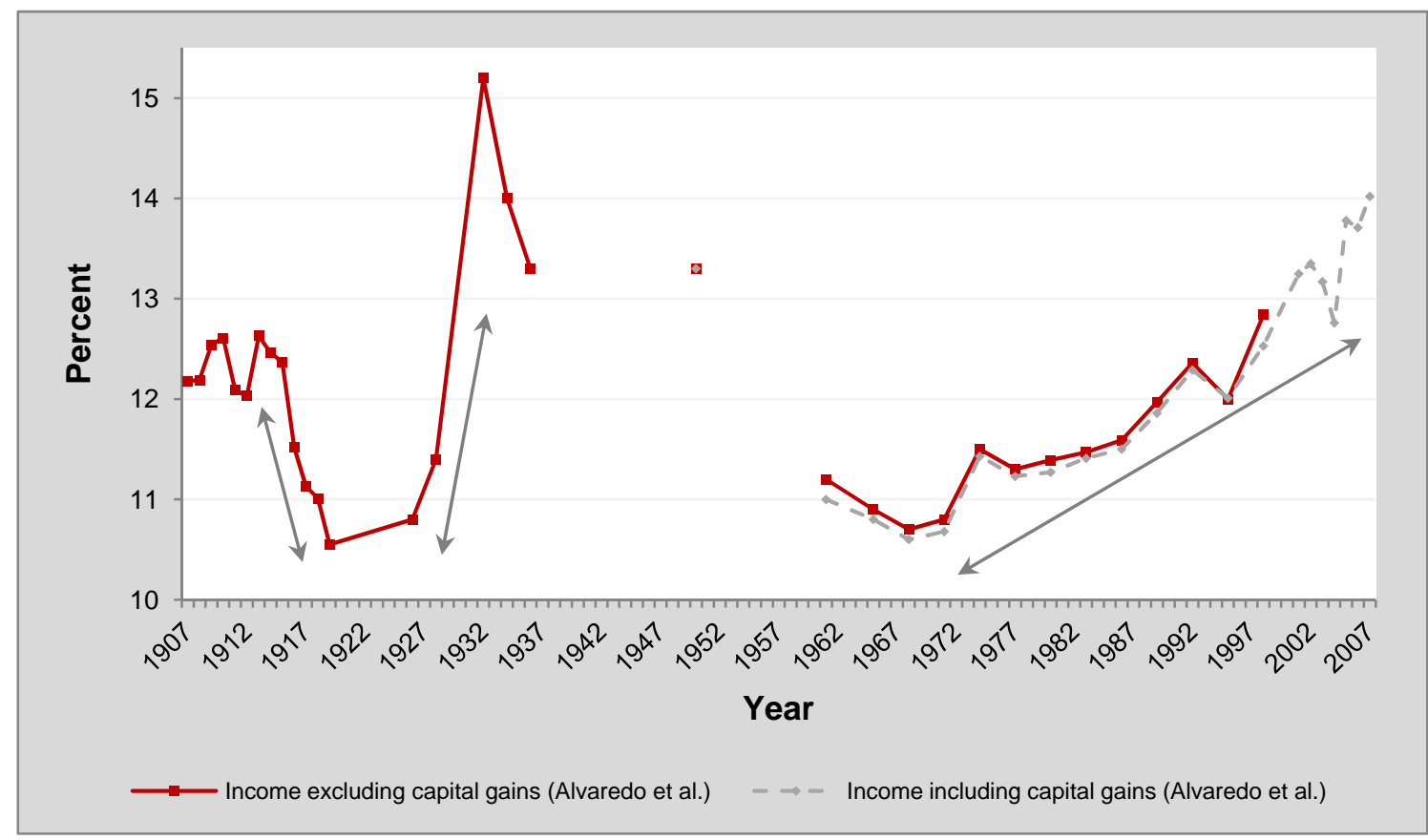

Source: Alvaredo et al. 2012, Table Germany. 
Figure B.4: The top percentile income share in Germany, 1907-2007

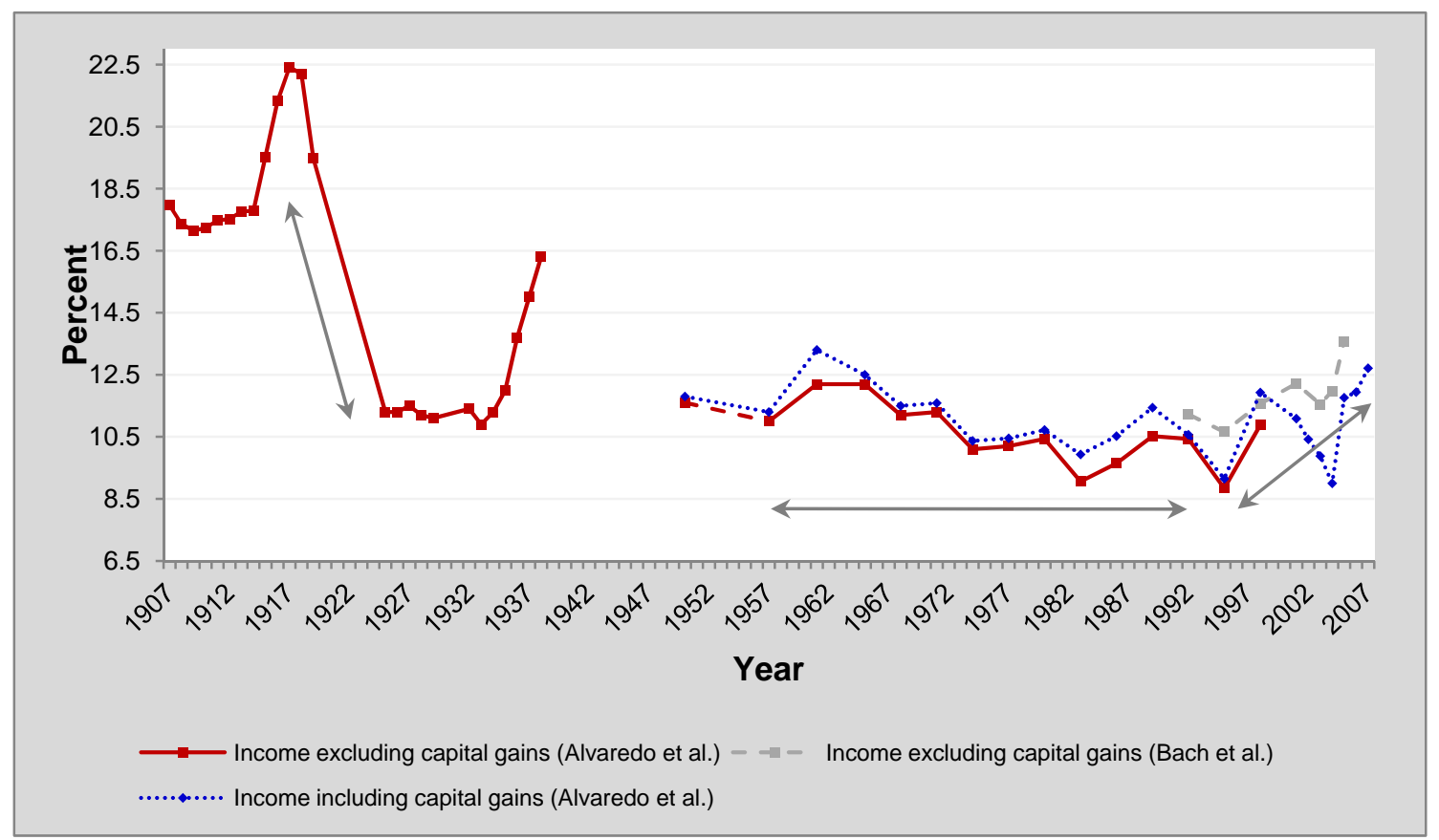

Source: Alvaredo et al. 2012, Table Germany; Bach et al. 2009, Table 3.

Figure B.5: The top 1-0.5 percent income share in Germany, 1907-2007

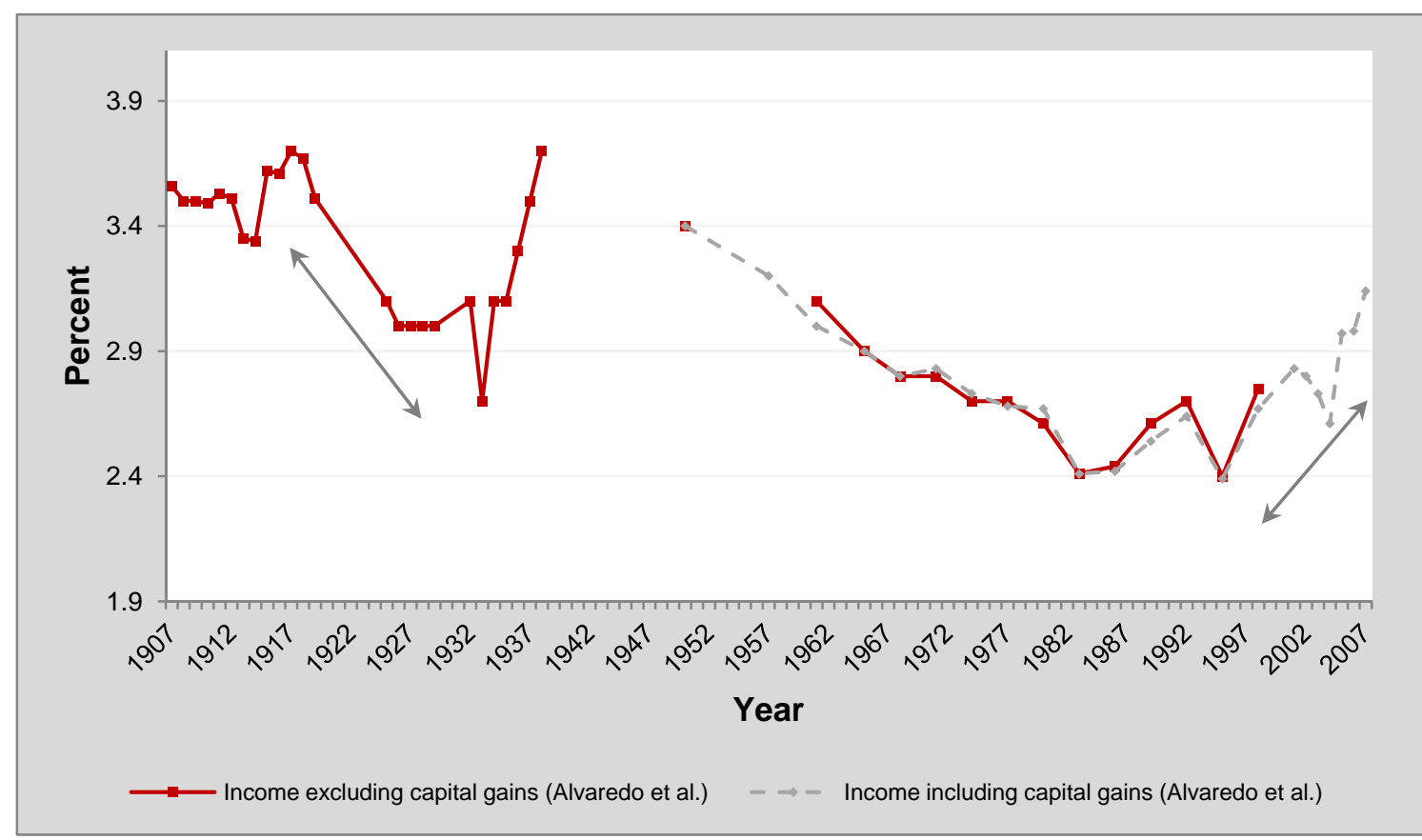

Source: Alvaredo et al. 2012, Table Germany. 
Figure B.6: The top 0.01 percent income share in Germany, 1907-2007

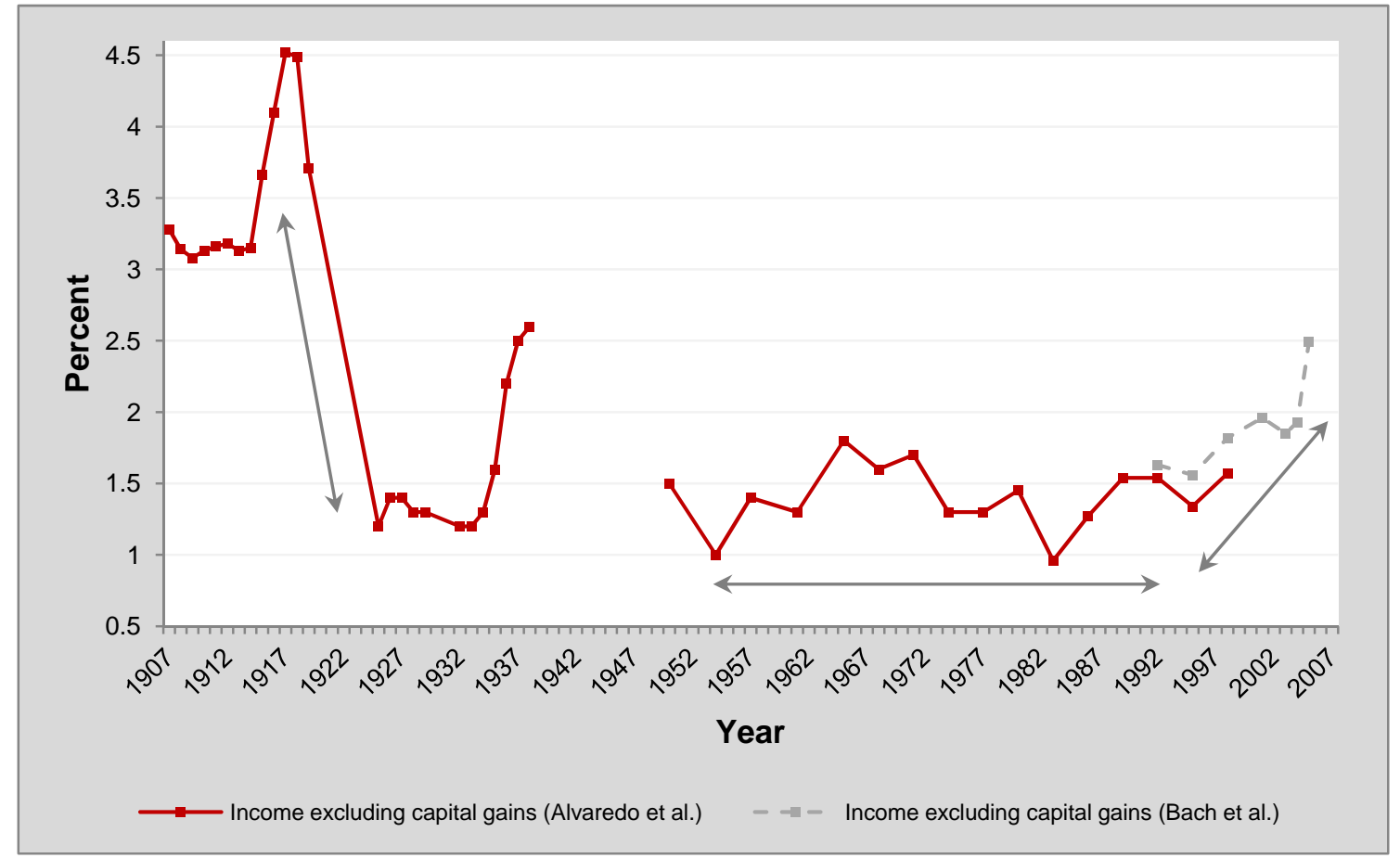

Source: Alvaredo et al. 2012, Table Germany; Bach et al. 2009, Table 3.

Table B.1: Average annual growth rates of real family gross income (including capital gains) across different income fractiles

\begin{tabular}{|c|c|c|c|c|c|c|c|c|c|}
\hline & Average & $\begin{array}{c}\text { Bottom } \\
90 \%\end{array}$ & $\begin{array}{c}\text { Bottom } \\
99 \%\end{array}$ & $\begin{array}{l}\text { Top } \\
10 \%\end{array}$ & Top 5\% & Top 1\% & $\begin{array}{l}\text { Top } \\
0.5 \%\end{array}$ & $\begin{array}{l}\text { Top } \\
0.1 \%\end{array}$ & $\begin{array}{c}\text { Top } \\
0.01 \%\end{array}$ \\
\hline $\begin{array}{l}1950- \\
1995\end{array}$ & 3.1 & 3.2 & 3.2 & 3.0 & 2.8 & 2.6 & 2.6 & 2.8 & 2.9 \\
\hline $\begin{array}{l}1995- \\
2007\end{array}$ & -0.2 & -1.0 & -0.6 & 1.3 & 1.7 & 2.5 & 2.7 & 3.2 & 3.8 \\
\hline
\end{tabular}

Source: Alvaredo et al. 2012, Table Germany; own calculations. 


\section{Appendix C: The composition of top incomes}

Figure C.1: Share of different income components within the top 0.1 percent (capital gains excluded) in the United States, 1916-2010

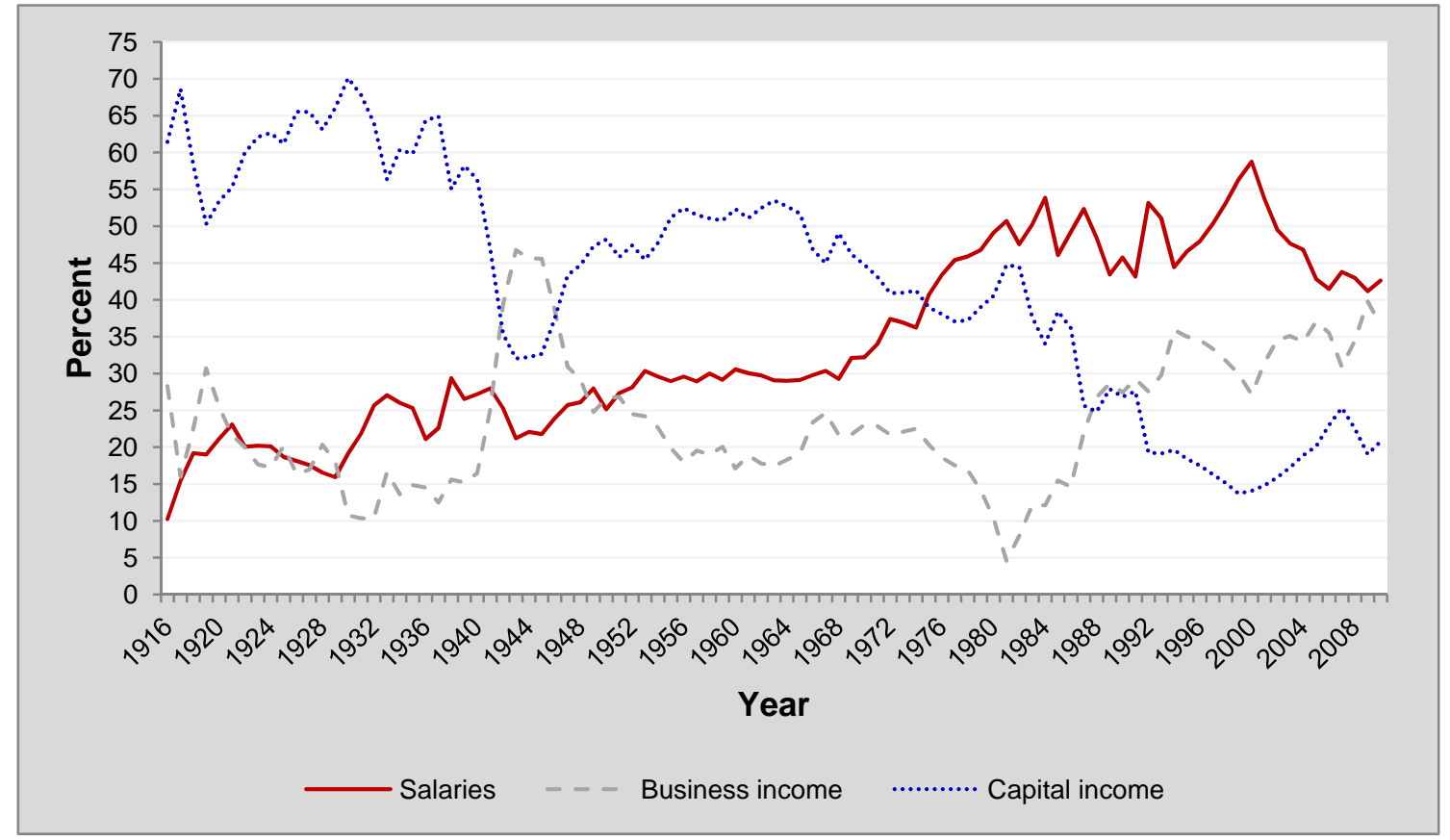

Source: Alvaredo et al. 2012, Table United States. 


\section{Literature}

Abelshauser, W. (1983). Wirtschaftsgeschichte der Bundesrepublik Deutschland 19451980. Frankfurt am Main: Suhrkamp Verlag.

Adler, M. \& Schmid, K. D. (2011). Factor shares and inequality, IAW Tübingen, December 2011, mimeo (paper presented at the 15th conference of 'The Research Network Macroeconomics and Macroeconomic Policies (FMM)' in Berlin on October 29, 2011).

Alvaredo, F. (2010). A Note on the Relationship between Top Income Shares and the Gini Coefficient, piketty.pse.ens.fr/files/Alvaredo2010.pdf; Access on April 04, 2012.

Alvaredo, F., Atkinson, A. B., Piketty, T. \& Saez, E. (2012). The World Top Incomes Database, http://g-mond.parisschoolofeconomics.eu/topincomes; Access on February 29, 2012.

Atkinson, A. B. (2001), A Critique of the Transatlantic Consensus on Rising Income Inequality. In The World Economy, vol. 24, no. 4, pp. 433-452.

Atkinson, A. B. (2007). Measuring Top Incomes: Methodological Issues. In A. B. Atkinson \& T. Piketty, Top Incomes over the Twentieth Century, New York: Oxford University Press, pp. 18-42.

Atkinson, A. B. (2008). The Changing Distribution of Earnings in OECD Countries. New York: Oxford University Press.

Atkinson, A. B. \& Piketty, T. (2007a). Top Incomes over the Twentieth Century. New York: Oxford University Press.

Atkinson, A. B. \& Piketty, T. (2007b). Towards a Unified Data Set on Top Incomes. In A. B. Atkinson \& T. Piketty, Top Incomes over the Twentieth Century, New York: Oxford University Press, pp. 531-565.

Atkinson, A. B. \& Piketty, T. (2010). Top Incomes: A Global Perspective. New York: Oxford University Press.

Atkinson, A.B., Piketty, T. \& Saez, E. (2011). Top Incomes in the Long Run of History. In Journal of Economic Literature, vol. 49, no. 1, pp. 3-71.

Bach, S., Corneo, G. \& Steiner, V. (2009). From bottom to top: The entire income distribution in Germany, 1992-2003. In The Review of Income and Wealth, series 55, no. 2, pp. 303-330.

Bach, S., Corneo, G. \& Steiner, V. (2011). Effective taxation of top incomes in Germany, www.wiwiss.fuberlin.de/institute/finanzen/corneo/dp/BCS_EffectTaxRate_2011-06-20.pdf; Access on March 01, 2012.

Bebchuk, L. A. \& Fried J. M. (2003). Executive Compensation as an Agency Problem. In Journal of Economic Perspectives, vol. 17, no. 3, pp. 71-92. 
Bebchuk, L. A. \& Fried J. M. (2004). Pay without Performance: The Unfulfilled Promise of Executive Compensation. Cambridge, MA: Harvard University Press.

Berg, A. G. \& Ostry, J. D. (2011). Inequality and Unsustainable Growth: Two Sides of the Same Coin?, www.imf.org/external/pubs/ft/sdn/2011/sdn1108.pdf; Access on April 09, 2012.

Congressional Budget Office. (2011). Trends in the Distribution of Household Income Between 1979 and 2007, http://cbo.gov/publication/42729; Access on March 18, 2012.

Dell, F. (2005). Top Incomes in Germany and Switzerland over the Twentieth Century, piketty.pse.ens.fr/fichiers/Dell2005.pdf; Access on March 31, 2012.

Dell, F. (2007). Top Incomes in Germany Throughout the Twentieth Century: 18911998. In A. B. Atkinson \& T. Piketty, Top Incomes over the Twentieth Century, New York: Oxford University Press, pp. 365-425.

DiNardo, J., Fortin, N. M. \& Lemieux, T. (1996). Labor Market Institutions and the Distribution of Wages, 1973-1992: A Semiparametric Approach. In Econometrica, vol.64, no.5, pp.1001-1044.

Eisenhardt, K. M. (1989). Agency theory: An assessment and review. In Academy of Managenent Review, vol. 14, no. 1, pp. 57-74.

German Socio-Economic Panel Study. (2010). SOEPmonitor 1984-2010: Time Series on selected Indicators about "Living in Germany", http://www.diw.de/de/diw_02.c.222727.de/soepmonitor.html; Access on March 16, 2012.

Goldin, C. \& Margo, R. A. (1991). The Great Compression: The Wage Structure in the United States at mid-century, www.nber.org/papers/w3817.pdf; Access on April 01, 2012.

Grabka, M. M. (2011). Probleme und Herausforderungen des "Modells Deutschland" am Beispiel der Mittelschicht. In Angenendt et al., Der deutsche Weg aus der Krise, Paris: KAS Publikation Deutsch-Französischer Dialog, pp. 76-94, www.kas.de/wf/doc/kas_23307-1522-1-30.pdf?110708111114; Access on March 18, 2012.

Grabka, M. M. \& Frick, J. R. (2008). Schrumpfende Mittelschicht - Anzeichen einer dauerhaften Polarisierung der verfügbaren Einkommen? In DIW Wochenbericht, no. 10/2008, Berlin: DIW, pp. 101-108.

Grossman, G. M. \& Rossi-Hansberg, E. (2008). Trading Tasks: A Simple Theory of Offshoring. In American Economic Review, vol. 98, no. 5, pp. 1978-1997.

Hall, B. J. \& Murphy, K. J. (2003). The Trouble with Stock Options, http://www.nber.org/papers/w9784; Access on April 08, 2012. 
Hao, L. \& Naiman, D. Q. (2010). Assessing Inequality (Series: Quantitative

Applications in the Social Sciences). Los Angeles et al.: SAGE Puclications, Inc.

Hauser, R. \& Krämer, H. M. (2011). Zunehmende Ungleichheit der Einkommens- und Vermögensverteilung. Empirische Entwicklungen in ausgewählten OECDLändern. In J. Kromphardt (ed.), Keynes' General Theory nach 75 Jahren, Marburg: Metropolis-Verlag, pp. 21-56.

Kim, C. \& Sakamoto, A. (2005). Bringing Inequality Back In: The Role of Occupational Structure in Growing Wage Dispersion, www.ccpr.ucla.edu/publications/conference-proceedings/CP-05-004.pdf; Access on February 28, 2012.

King, W. I. (1915). The Wealth and Income of the People of the United States. New York: MacMillan \& Co., Ltd.

Krämer, H. M. (2011). Die Entwicklung der funktionalen Einkommensverteilung und ihrer Einflussfaktoren in ausgewählten Industrieländern 1960-2010, IMK Studies no. 1/2011, Düsseldorf: Hans-Böckler-Stiftung.

Krueger, A. (1974). The Political Economy of the Rent-Seeking Society. In American Economic Review, vol. 64, no. 3, pp. 291-303.

Krugman, P. (2007). The Conscience of a Liberal (Blog, The New York Times), http://krugman.blogs.nytimes.com/2007/09/18/introducing-this-blog/; Access on March 31, 2012.

Kuznets, S. (1953). Shares of Upper Income Groups in Income and Savings. New York: National Bureau of Economic Research.

Lazear, E. P. \& Rosen, S. (1981). Rank-Order Tournaments as Optimum Labor Contracts. In Journal of Political Economy, vol. 89, no. 5, pp. 841-864.

Lydall, H. F. (1968). The Structure of Earnings. Oxford: Clarendon Press.

Martocchio, J. J. (2011). Strategic Compensation: A Human Resource Management Approach. Boston et al.: Pearson Prentice Hall.

OECD. (2008). Growing Unequal? Income Distribution and Poverty in OECD Countries. Paris: OECD Publishing.

OECD. (2011a). Divided We Stand: Why Inequality Keeps Rising. Paris: OECD Publishing.

OECD. (2011b). Inequality: Why the struggle matters (OECD Observer no. 287, Q4 2011). Paris: OECD Publications.

OECD. (2012a). OECD Factbook 2011-2012: Economic, Environmental and Social Statistics. Paris: OECD Publishing.

OECD. (2012b). Income distribution - Inequality - Country tables, http://stats.oecd.org/Index.aspx?DataSetCode=CSP2011; Access on March 03, 2012. 
O'Reilly, C. A. \& Main, B. G. (2007). Setting the CEO's pay: It's More Than Simple Economics. In Organizational Dynamics, vol. 36, no. 1, pp. 1-22.

O'Reilly, C. A. Main, B. G. \& Crystal, G. S. (1988). CEO Compensation as Tournament and Social Comparison: A Tale of Two Theories. In Administrative Science Quarterly, vol. 33, no. 2, pp. 257-274.

Phelps Brown, H. (1977), The Inequality of Pay, Oxford: Oxford University Press.

Piketty, T. (2007). Top Incomes Over the Twentieth Century: A Summary of Main Findings. In A. B. Atkinson, \& T. Piketty, Top Incomes over the Twentieth Century, New York: Oxford University Press, pp. 1-17.

Piketty, T. \& Saez, E. (2007). Income and Wage Inequality in the United States, 19132002. In A. B. Atkinson, \& T. Piketty, Top Incomes over the Twentieth Century, New York: Oxford University Press, pp. 141-225.

Saez, E. (2005). Top Incomes in the United States and Canada over the Twentieth Century. In Journal of the European Economic Association, vol. 3, no. 2-3, pp. 402411.

Saez, E. (2012a). Public Economics: Taxable Income Elasticities, elsa.berkeley.edu/ saez/course/Labortaxes/taxableincome/taxableincomeslides.pdf; Access on April 01, 2012.

Saez, E. (2012b). Striking it Richer: The Evolution of Top Incomes in the United States (Updated with 2009 and 2010 estimates), http://184.168.89.58/sketch/saezUStopincomes-2010.pdf; Access on March 05, 2012.

Schwarze, J. (1998). Der Einfluß alternativer Konzeptionen von Alterssicherungssystemen auf Sicherungsniveau, Altersarmut und Einkommensverteilung: Ein Vergleich zwischen Deutschland und den USA (DIW Discussion Papers). Berlin: DIW.

Tosi, H. L. \& Gomez-Meija L. R. (1989), The Decoupling of CEO Pay and Performance: An Agency Theory Perspective. In Administrative Science Quarterly, vol. 34, no. 2, pp. 169-189. 